\title{
Consultas populares y entidades locales: a propósito de la Ley 7/2017, de 27 de diciembre, de Participación Ciudadana de Andalucía
}

\author{
Popular consultations and local entities: concerning the Regulation \\ 7/2017, from $27^{\text {th }}$ december, about Andalusian Citicen's \\ Participation
}

\author{
Inmaculada Ruiz Magaña \\ Universidad de Jaén (España) \\ ORCID: https://orcid.org/0000-0002-2466-7235 \\ irmagana@ujaen.es
}

\section{NOTA BIOGRÁFICA}

Graduada en Derecho y Máster de Abogacía por la Universidad de Jaén. En la actualidad es contratada predoctoral en el programa nacional de Formación de Profesorado Universitario (FPU) del Ministerio de Ciencia, Innovación y Universidades en el Área de Derecho Administrativo de la Universidad de Jaén.

\section{RESUMEN}

En la Comunidad Autónoma de Andalucía las consultas populares municipales fueron objeto de tratamiento normativo en la Ley 2/2001, de 3 de mayo, de Regulación de las Consultas Populares Locales en Andalucía. En 2018 el legislador autonómico ha promulgado la Ley 7/2017, de 27 de diciembre, de Participación Ciudadana de Andalucía, que presenta como principal novedad la instauración en los niveles autonómico y local de diversos canales y procedimientos de participación entre los que se encuentran las consultas populares. Concretamente, destaca la figura de las consultas participativas («instrumento de consulta popular» que crea la norma) mediante la que se regulan por primera vez las consultas de ámbito supramunicipal e inframunicipal y se incide nuevamente en el régimen de las de ámbito municipal, que contarán con una doble regulación. Estas circunstancias delimitan el objeto de este trabajo que se centra en estudiar cómo queda configurado el régimen jurídico de las consultas populares locales en Andalucía tras la entrada en vigor de la Ley.

\section{PALABRAS CLAVE}

Comunidad Autónoma de Andalucía; consultas participativas sectoriales; consultas populares locales referendatarias; consultas populares locales no referendatarias; entidades locales.

\begin{abstract}
In the Autonomous Community of Andalusia, the municipal popular consultations were covered by the Regulation 2/2001, from 3rd of May, about the regulation of Local Popular Consultations in Andalusia. In 2018, the regional legislator enacted the Regulation 7/2017, from 27th December, about Andalusian Citizen's Participation, which introduces as its main update the establishment at regional and local levels, of various channels and processes of participation, among which are found the participatory consultations. Concretely, it is by the use of the figure of participatory consultations («instrument of popular consultation»
\end{abstract}


REALA. Nueva Época - N.o 13, abril-septiembre 2020 - ISSN: 1989-8975 - DOI: 10.24965/reala.i13.10741 - [Págs. 47-74]

Consultas populares y entidades locales: a propósito de la Ley 7/2017, de 27 de diciembre, de Participación Ciudadana de Andalucía

created by the Regulation) through which are regulated for first time the supramunicipal and inframunicipal consultations, and again there is an impact on the regime of those at the municipal level, which would count with a double regulation. These circumstances delimit the target of this work which focuses on the study of how the legal regime of local popular consultations in Andalusia is being shaped after the implementation of that regulation.

\section{KEYWORDS}

Autonomous Community of Andalusia; local popular consultations; local entities; referendum; sectoral participatory consultations.

\section{SUMARIO}

1. INTRODUCCIÓN. 2. EL RÉGIMEN GENERAL DE LAS CONSULTAS POPULARES EN ANDALUCÍA HASTA LA LEY 7/2017. 2.1. MARCO NORMATIVO ESTATAL. 2.2. LAS PREVISIONES DE LOS ESTATUTOS DE AUTONOMÍA DE ANDALUCÍA EN LA MATERIA. 2.3. LA LEY 2/2001 DE CONSULTAS POPULARES LOCALES DE ANDALUCÍA. 2.3.1. Delimitación y ámbito de aplicación. 2.3.2. Procedimiento. 2.4. UTILIZACIÓN PRÁCTICA EN ANDALUCÍA. 3. CONSULTAS LOCALES Y PARTICIPACIÓN CIUDADANA EN LA LEY 7/2017. 3.1. GENERALIDADES. 3.2. LOS PROCEDIMIENTOS DE PARTICIPACIÓN CIUDADANA MEDIANTE CONSULTAS POPULARES. 3.2.1. Instrumentos de consulta popular. 3.2.2. Las consultas participativas sectoriales locales. 4. UNA REFLEXIÓN FINAL. ANEXO. "CONSULTAS POPULARES CELEBRADAS EN ANDALUCÍA». REFERENCIAS BIBLIOGRÁFICAS.

\section{INTRODUCCIÓN¹}

El sistema tradicional de democracia representativa se ha visto complementado con la progresiva implantación de instrumentos de democracia participativa que permiten que la soberanía sea ejercida directamente por el pueblo sin la intermediación de representantes. En el ámbito local ha sido siempre pionero como referente el régimen de Concejo Abierto, regulado en el art. 140 de la Constitución Española de 29 de diciembre de 1978 (en adelante CE) y en el art. 29 de la Ley 7/1985, de 2 de abril, Reguladora de las Bases del Régimen Local (en adelante LBRL). Como es sabido, se trata de una forma organizativa de la vida local que implica adoptar un sistema de democracia participativa directa en el que el gobierno y administración municipales corresponden a un Alcalde y una asamblea vecinal de la que forman parte todos los electores (art. 29.3 LBRL) ${ }^{2}$. Fue en el avance democrático de los años sesenta cuando la participación de los ciudadanos se convirtió en una «nueva ideología político jurídica» que pretendía extenderse a las funciones ejercidas por los poderes públicos ${ }^{3}$. Sin embargo, en el ámbito de la Administración Pública la participación de la ciudadanía ya se encontraba presente en distintos ámbitos. Así lo defendió en la década de los setenta, calificada por la doctrina alemana como «época de la euforia participativa», GARCÍA DE ENTERRÍA que delimitó tres círculos de actuación ciudadana sobre las funciones administrativas: i) Una «actuación orgánica», ordenada sobre el modelo corporativo, en la que el ciudadano se incorpora a órganos estrictamente de la Administración. ii) Una «actuación funcional» en la que el ciudadano ejerce funciones administrativas desde su propia posición privada, sin incorporarse a un órgano administrativo formal. Y, iii) una «actuación cooperativa» en la que el administrado sin dejar de actuar como tal colabora de manera voluntaria en programas

1 Este trabajo ha sido realizado en el marco del Proyecto I+D+i del Plan Nacional, Las Entidades Locales, sus relaciones y competencias. Realidad, efectos y consecuencias de la racionalización y sostenibilidad financiera en clave nacional y europea (DER201674843-C3-1-R), del que es Investigadora Principal la Prof. Eloísa Carbonell Porras, que se desarrolla en el seno de la Estructura de Investigación de la Universidad de Jaén EI_SEJ9_2019 y del Grupo de Investigación PAIDI SEJ-630, Administración Pública y Ciudadanos: régimen jurídico (APCl), que también dirige la Prof. Carbonell Porras.

2 Sobre el régimen de Concejo Abierto vid. COSCULLUELA MONTANER, L. (1987): "El Concejo Abierto", en Revista de Estudios de la Administración Local y Autonómica, núm. 234, págs. 199-294, CARBONELL PORRAS, E. (2005): "Concejo Abierto", en MUCHOZ MACHADO, S. (dir.): Diccionario de Derecho Administrativo. Madrid: lustel (Tomo I), págs. 546-556 y PIZARRO NEVADO, R. (2007): “Artículo 29", en REBOLLO PUIG, M. (dir.): Comentarios a la Ley Reguladora de las Bases del Régimen Local. Valencia: Tirant lo Blanch (Tomo I), págs. 755-771.

3 Así lo señala SÁNCHEZ MORÓN, M. (1979): "El principio de participación en la Constitución Española", en Revista de Administración Pública, núm. 89, págs. 173 y 174. 
REALA. Nueva Época - N.o 13, abril-septiembre 2020 - ISSN: 1989-8975 - DOI: 10.24965/reala.i13.10741 - [Págs. 47-74]

Consultas populares y entidades locales: a propósito de la Ley 7/2017, de 27 de diciembre, de Participación Ciudadana de Andalucía

o actividades que la administración patrocina y promueve ${ }^{4}$. Por su parte, los constituyentes conocedores de los movimientos de su tiempo acogieron en la CE referencias a la participación en distintos ámbitos (entre otros, en los arts. 9.2, 23.1, 27.5, 48, 105, 125 y 129.1). De estos preceptos deben destacarse fundamentalmente dos. El art. 9.2, que atribuye a los poderes públicos la obligación de «facilitar la participación de todos los ciudadanos en la vida política, económica, cultural y social», y el art. 105, que constitucionaliza y establece una reserva de ley sobre la audiencia de los ciudadanos en el procedimiento de elaboración de las disposiciones administrativas que les afecten -apartado a) - y la audiencia al interesado en el procedimiento administrativo -apartado b)-.

En el ámbito local la concreción de estos postulados constitucionales se hace en la LBRL. El art. 1 resalta el papel de los municipios como «cauces inmediatos de participación ciudadana en los asuntos públicos» y el art. 18.1.b) realiza un reconocimiento genérico del derecho de los vecinos a participar en la gestión municipal. La Ley incluso dedica un Capítulo a la «Información y participación ciudadanas» (Capítulo IV del Título V, arts. 69 a 72). El Consejo de Europa también ha contribuido a dar continuidad a esta idea. Pueden destacarse, por una parte, el Preámbulo de la Carta Europea de Autonomía Local de 15 de octubre de 1985 que considera que la existencia de entidades locales «permite una administración a la vez eficaz y próxima al ciudadano» y, por otra parte, la Recomendación 19 del Comité de Ministros del Consejo de Europa, de 6 de diciembre de 2001, sobre la participación ciudadana en la vida pública local ${ }^{5}$. En esta misma línea, la Unión Europea ha aprobado el Libro Blanco sobre La Gobernanza Europea, de 25 de julio de 2001, que propone a los Estados fomentar la participación ciudadana en la vida democrática de la Unión llegando al ciudadano por la vía de la democracia regional y local ${ }^{6}$. El legislador español, conocedor de esta tendencia continental, consideraba como «insuficiente» el tratamiento que la LBRL hacía de la participación ciudadana y trató de reforzar esta deficiencia mediante la Ley 57/2003, de 16 de diciembre, de medidas para la modernización del gobierno local (a modo de ejemplo, entre otras medidas introducidas, se pueden señalar la regulación de la iniciativa legislativa popular en el art. 70 bis 2 o la imposición a los municipios de gran población de la obligación de crear distritos para impulsar y desarrollar la participación ciudadana en la gestión de asuntos municipales en el nuevo apartado 2 del art. 24 y en el art. 128).

En este contexto, la Comunidad Autónoma andaluza se ha ocupado de la participación ciudadana recientemente. En 2018 se ha publicado la Ley 7/2017, de 27 de diciembre, de Participación Ciudadana de Andalucía (en adelante Ley 7/2017) que presenta como especial novedad en Andalucía la regulación en un mismo cuerpo legal de instrumentos y canales de participación de nivel autonómico y local ${ }^{7}$. En concreto, regula medidas de fomento de participación ciudadana y procedimientos de participación entre los que se encuentran las consultas populares. Estas últimas ya se regularon por la Ley $2 / 2001$, de 3 de mayo, de regulación de las consultas populares locales en Andalucía (en adelante Ley 2/2001), que continúa en vigor. Precisamente, el objeto de este trabajo es realizar un estudio sobre la configuración del régimen jurídico de consultas populares locales en la Comunidad Autónoma de Andalucía tras la Ley 7/2017. Con este fin, el trabajo se estructura en dos bloques. En el primero, que se sitúa en un momento previo a la aprobación de la Ley $7 / 2017$, se hace una breve referencia al tratamiento normativo de las consultas populares en los ámbitos estatal y autonómico de Andalucía (en particular, en este último se atiende a las previsiones estatutarias y de la Ley 2/2001), así como a la utilización práctica de las consultas populares en la Comunidad Autónoma. Sobre esta base, en el segundo bloque se centra la atención en la Ley 7/2017. Primero se hace una mención a su contenido general y seguidamente a los procedimientos de participación ciudadana mediante consultas populares, en especial a los procedimientos de consultas participativas que, como se verá, son a los que el legislador autonómico presta una mayor atención.

\footnotetext{
4 GARCÍA DE ENTERRÍA, E. (1977): “La participación del administrado en las funciones administrativas”, en AA.VV: Homenaje a Segismundo Royo-Villanova. Madrid: Moneda y Crédito, pág. 307. Como indica MUÑOZ MACHADO, S. lo que se busca fundamentalmente con esta participación en el ámbito administrativo es ofrecer un cauce a la expresión de las demandas sociales que sea también útil para controlar las decisiones que las autoridades administrativas adoptan en el marco de sus poderes discrecionales (1977): "Las concepciones del Derecho Administrativo y la idea de participación en la Administración", en Revista de Administración Pública, núm. 84, pág. 532.

5 [15-05-2019]. La Recomendación 19 del Comité de Ministros del Consejo de Europa está disponible en web: http://www.seat. mpr.gob.es/dam/es/portal/areas/politica_local/participacion-eell-aeuropeos/recomendacion.pdf.

6 DOCE, 12 de octubre de 2001, C 287/1.

7 BOJA, núm. 4, de 5 de enero de 2018.
} 


\section{EL RÉGIMEN GENERAL DE LAS CONSULTAS POPULARES LOCALES EN ANDALUCÍA HASTA LA LEY 7/2017}

\subsection{Marco normativo estatal}

Como es sabido, el art. 149.1 CE contiene una enumeración de las «materias» sobre las que el «Estado tiene competencia exclusiva». En concreto, es el apartado $32 . .^{\circ}$ del referido precepto el que se aproxima a lo que constituye el objeto de este estudio y reserva al Estado la competencia sobre la «autorización para la convocatoria de consultas populares por vía de referéndum». Por lo tanto, lo reservado al Estado no es la materia completa sobre consultas populares sino la competencia sobre la autorización de aquellas que se celebren por vía de referéndum ${ }^{8}$. En consecuencia, los restantes aspectos relativos a la materia indicada pueden ser competencia de las Comunidades Autónomas si así lo prevén sus respectivos Estatutos de Autonomía. Si bien, en su defecto, de no ser asumidas por estos últimos corresponderán al Estado de conformidad con el art. 149.3 CE. No obstante lo anterior, FONT I LLOVET advierte que para que las Comunidades Autónomas puedan legislar sobre las consultas populares no es necesario que los Estatutos contengan expresa referencia a las mismas, sino que es suficiente con que ostenten competencias sobre el régimen local (art. 149.1.18. $\left.{ }^{\circ} \mathrm{CE}\right)^{9}$.

La previsión del art. 149.1.32. ${ }^{\circ} \mathrm{CE}$ conecta con el art. 92.3 CE que establece una reserva de ley orgánica para regulación de «las condiciones y el procedimiento de las distintas modalidades de referéndum» previstas en la CE. En cumplimiento de este mandato se desarrolla la Ley Orgánica 2/1980, de 18 de enero, sobre regulación de las distintas modalidades de referéndum (en adelante LO 2/1980) que no resulta de aplicación a las consultas populares locales, pues su disposición adicional las excluye en los siguientes términos:

«Las disposiciones de la presente Ley no alcanzan en su regulación a las consultas populares que puedan celebrarse por los Ayuntamientos, relativas a asuntos relevantes de índole municipal, en sus respectivos territorios, de acuerdo con la legislación de Régimen Local, y a salvo, en todo caso, la competencia exclusiva del Estado para su autorización».

De este modo, la regulación de las consultas populares responde a un régimen jurídico propio que según esta Ley debe aprobarse de acuerdo con la legislación de régimen local. Ha sido la LBRL la que ha abordado la materia, aunque como corresponde con la idea de lo básico lo hace con un carácter sucinto y con amplios reenvíos normativos. El art. 18.1.f) reconoce el derecho de los vecinos a pedir la celebración de consultas populares «en los términos previstos por la ley». Y, en desarrollo del mismo, el art. 71 establece que:

«De conformidad con la legislación del Estado y de la Comunidad Autónoma, cuando ésta tenga competencia estatutariamente atribuida para ello, los Alcaldes, previo acuerdo por mayoría absoluta del Pleno y autorización del Gobierno de la Nación, podrán someter a consulta popular aquellos asuntos de la competencia propia municipal y de carácter local que sean de especial relevancia para los intereses de los vecinos, con excepción de los relativos a la Hacienda Local».

Como señalan FERNÁNDEZ RAMOS y RIVERO YSERN, del precepto se infiere que se trata de consultas populares que no pueden exceder del ámbito municipal ${ }^{10}$. Tras esta aseveración FERNÁNDEZ RAMOS

8 Vid. REBOLLO PUIG, M. (2017a): "Relaciones entre el ordenamiento estatal y los autonómicos", en REBOLLO PUIG, M. y VERA JURADO, D. (dirs.): Derecho Administrativo. Madrid: Tecnos (Tomo I), pág. 117. Para COSCULLUELA MONTANER, L. dicha atribución competencial al Estado se justifica «con el control del uso del potencial político que encierra toda consulta popular (...) susceptible de plantear tensiones políticas con el Estado que podrían incidir en la unidad jurídica y política del propio Estado» (1979): "La determinación constitucional de las competencias de las Comunidades Autónomas", en Revista de Administración Pública, núm. 89, págs. 26 y 27.

9 FONT I LLOVET, T. (1985): "El referéndum local en España”, en Revista Catalana de Dret Public, núm. 2-3, pág. 127.

10 FERNÁNDEZ RAMOS, S. (2007): "Artículo 71", en REBOLLO PUIG, M. (dir.): Comentarios a la Ley reguladora de las Bases del Régimen Local. Valencia: Tirant lo Blanch (Tomo II), págs. 1.812 y 1.813. RIVERO YSERN, J. L. (2014): Manual de Derecho Local. Huarte: Civitas, pág. 137. Es sabido que según la organización territorial del Estado consagrada por la CE son Administraciones públicas territoriales los Municipios, las Provincias y las Islas de los archipiélagos balear y canario (arts. 140 y $141 \mathrm{CE}$ ). También pueden existir otras Entidades locales como son las comarcas (u otras agrupaciones de municipios), las áreas metropolitanas y las mancomunidades de municipios, que carecen de protección constitucional y tienen por tanto un régimen jurídico distinto. Esta diferente posición constitucional se recoge en el art. 3 LBRL, que primero se refiere a las entidades locales territoriales constitucionalmente garantizadas -Municipios, 
REALA. Nueva Época - N. 13, abril-septiembre 2020 - ISSN: 1989-8975 - DOI: 10.24965/reala.i13.10741 - [Págs. 47-74]

Consultas populares y entidades locales: a propósito de la Ley 7/2017, de 27 de diciembre, de Participación Ciudadana de Andalucía

apunta que «cabría plantearse la posibilidad de delimitar un ámbito de consulta inframunicipal -un distrito, una entidad local menor...-» aunque seguidamente concluye que de la delimitación del objeto de la consulta (asuntos de competencia propia municipal de especial transcendencia para los vecinos) parece desprenderse que las consultas han de convocar en todo caso al conjunto de los vecinos del municipio ${ }^{11}$.

\subsection{Las previsiones de los Estatutos de Autonomía de Andalucía en la materia}

Como se ha indicado, los Estatutos de Autonomía determinan si atribuyen competencia a sus respectivas Comunidades Autónomas sobre las materias no asignadas expresamente al Estado. En 1981 la Comunidad Autónoma de Andalucía asumió a través del art. 15.2 de la Ley Orgánica 6/1981, de 30 de diciembre, del Estatuto de Autonomía para Andalucía (en adelante EAAnd 1981) competencia para «el desarrollo legislativo del sistema de consultas populares locales en el ámbito de Andalucía» ${ }^{12}$. Así, el reparto de competencias sobre la materia quedaba articulado sobre el clásico sistema bases-desarrollo estando reservado al Estado el establecimiento de la legislación básica y a Andalucía la legislación restante y toda la ejecución; esto sin perjuicio de la función ejecutiva reservada al Estado por el art. 149.1.32. ${ }^{\circ} \mathrm{CE}$ de la autorización la convocatoria.

En el año 2007 el EAAnd 1981 es derogado por la Ley Orgánica 2/2007, de 19 de marzo, de reforma del Estatuto de Autonomía para Andalucía (en adelante EAAnd 2007) y con este el régimen de las consultas populares queda alterado. Con carácter general, los Estatutos de Autonomía reformados a partir de 2006 se caracterizan por una marcada de voluntad de profundizar en los mecanismos de participación ciudadana y buena muestra de ello se contiene en el EAAnd $2007^{13}$. El nuevo texto encomienda a la Comunidad Autónoma ejercer sus poderes de acuerdo con una serie de objetivos básicos entre los que se encuentra el fomento de la calidad de la democracia a través de la participación -tanto individual como asociada- de todos los andaluces en la elaboración, prestación y evaluación de las políticas públicas en los ámbitos cívico, social, cultural, económico y político (apartados 1 y $3.19 .^{\circ}$ del art. 10). En esta línea, realiza diversas referencias a la participación (arts. 5.3, 6.1, 26.2, 31, 113, 134 o 154, entre otros). Concretamente, alude a las consultas populares doblemente. En primer lugar, en el art. 30 («Participación política») reconoce a los andaluces el derecho a participar en los asuntos públicos de Andalucía, siendo una de sus manifestaciones «el derecho a promover la convocatoria de consultas populares por la Junta de Andalucía o por los Ayuntamientos, en los términos que establezcan las leyes» (apartado 1.c) y, en segundo lugar, en desarrollo del mismo el art. 78 «Consultas populares» determina que:

«Corresponde a la Junta de Andalucía la competencia exclusiva para el establecimiento del régimen jurídico, las modalidades, el procedimiento, la realización y la convocatoria por ella misma o por los entes locales en el ámbito de sus competencias de encuestas, audiencias públicas, foros de participación y cualquier otro instrumento de consulta popular, con la excepción del referéndum».

Provincias e Islas- y después a otras entidades locales de ámbito superior al municipio. La LBRL también contemplaba como Entidades locales a las de ámbito territorial inferior al municipal (antiguo art. 3.2.a) que han sido suprimidas por la Ley 27/2013, de 27 de diciembre, de racionalización y sostenibilidad de la Administración Local (en adelante LRSAL). Si bien, de acuerdo con las disposiciones transitorias cuarta y quinta de la LRSAL debe entenderse que no se han eliminado las entidades inframunicipales que ya existían o que estuviesen en procedimiento de constitución. Sobre la planta local vid. CARBONELL PORRAS, E. (2013): "La planta local: análisis general y perspectivas de reforma", en DÍEZ SÁNCHEZ, J. J. (coord.): La planta del gobierno local. Barcelona: Fundación Democracia y Gobierno Local, págs. 17-60 y (2014): "Sobre la reforma local y las competencias municipales propias", en Revista Vasca de Administración Pública, núm. especial 99-100, págs. 765-781 y PIZARRO NEVADO, R. (2017): "Entidades y «entes» de ámbito territorial inferior al municipio tras la reforma local de 2013”, en Revista de Estudios de la Administración Local y Autonómica, núm. 8, págs. 47-73.

11 Dado que la extensión de este trabajo impide entrar en el contenido del art. 71 para un estudio detallado del mismo vid., por todos, FERNÁNDEZ RAMOS, S. (2007: 1.799-1.842).

12 El art. 15.2 disponía que "Corresponde a la Comunidad Autónoma el desarrollo legislativo del sistema de consultas populares locales en el ámbito de Andalucía, de conformidad con lo que dispongan las leyes a que se refiere el apartado 3 del artículo 92 y el número 1 y 32 del artículo 149.1, de la Constitución, correspondiendo al Estado la autorización de su convocatoria». Sobre este precepto vid. JIMÉNEZ-BLANCO Y CARRILLO DE ALBORNOZ, A. (1987): "Artículo 15.2", en MUÑOZ MACHADO, S. (dir.): Comentarios al Estatuto de Autonomía de la Comunidad Autónoma de Andalucía. Madrid: Ministerio para las Administraciones Públicas e Instituto de Estudios de la Administración Local, págs. 419-426.

13 Así lo apuntan, PÉREZ ALBERDI, M. R. (2008): "Los derechos de participación en los Estatutos de Autonomía reformados recientemente: especial consideración al Estatuto de Autonomía para Andalucía”, en Revista de Derecho Político, núm. 73, págs. 181205, MARTÍN NÚÑ̃EZ, E. (2012): "El referéndum y las consultas populares en las comunidades autónomas y municipios", en Revista Vasca de Administración Pública, núm. 94, págs. 95-96 y RUIZ-RICO RUIZ, C. y CASTEL GAYÁN, S. (2013): "El derecho autonómico de participación ciudadana: un enfoque constitucional y su desarrollo legislativo", en Revista de Estudios Jurídicos, núm. 13, pág. 18. 
REALA. Nueva Época - N.o 13, abril-septiembre 2020 - ISSN: 1989-8975 - DOI: 10.24965/reala.i13.10741 - [Págs. 47-74]

Consultas populares y entidades locales: a propósito de la Ley 7/2017, de 27 de diciembre, de Participación Ciudadana de Andalucía

Inmaculada Ruiz Magaña notas.

De este precepto, y de su confrontación con el art. 15.2 EAAnd 1981, pueden destacarse las siguientes

Primero. Exceptúa el referéndum y generaliza el concepto de consulta popular con el de otras formas de participación que califica como «instrumentos de consulta popular» que, por tanto, tienen carácter no referendatario. De este modo, como indica BUENO ARMIJO a quien seguimos a continuación, la Junta de Andalucía adquiere nuevas competencias pero al mismo tiempo (si se considera que lo que regulaba el art. 15.2 EAAnd 1981 tiene carácter de referéndum local) «parece» renunciar a otras que ya tenía. Siguiendo al autor, lo anterior sirve de base para diferenciar dos categorías ${ }^{14}$.

a) Por una parte, las «consultas populares no celebradas por vía de referéndum» que son las encuestas, audiencias públicas, foros de participación así como aquellas otras modalidades que se creen en virtud de la cláusula abierta "cualquier otro instrumento de consulta popular» del art. 78 EAAnd 2007. A este respecto debe traerse a colación la doctrina constitucional sentada en la STC 31/2010, de 28 de junio, dictada con ocasión de un recurso de inconstitucionalidad interpuesto en relación con diversos preceptos de la Ley Orgánica 6/2006, de 19 de julio, de reforma del Estatuto de Autonomía de Cataluña. El Tribunal Constitucional, define el referéndum como:

«(...) una especie del género 'consulta popular' ... cuyo objeto se refiere estrictamente al parecer del cuerpo electoral (expresivo de la voluntad del pueblo: STC 12/2008, de 29 de enero, FJ 10) conformado y exteriorizado a través de un procedimiento electoral, esto es, basado en el censo, gestionado por la Administración electoral y asegurado con garantías jurisdiccionales específicas, siempre en relación con los asuntos públicos cuya gestión, directa o indirecta, mediante el ejercicio del poder político por parte de los ciudadanos constituye el objeto del derecho fundamental reconocido por la Constitución en el art. 23 (así, STC 119/1995, de 17 de julio) (STC 103/2008, FJ 2)» (FJ 69).

Y, seguidamente admite la legalidad de estos instrumentos de consulta popular en los siguientes términos:

«Caben, pues, consultas populares no referendarias mediante las cuales "se recaba la opinión de cualquier colectivo sobre cualesquiera asuntos de interés público a través de cualesquiera procedimientos" distintos de los que cualifican una consulta como referéndum (STC $103 / 2008$, FJ 2) y con los límites materiales a los que también hicimos referencia en la STC 103/2008 (FJ 4) respecto de todo tipo de consultas, al margen de la prevista en el art. 168 CE. Las encuestas, audiencias públicas y foros de participación a los que se refiere el art. 122 EAC tienen perfecto encaje en aquel género que, como especies distintas, comparten con el referéndum. Si a ello se añade que las consultas previstas en el precepto se ciñen expresamente al ámbito de las competencias autonómicas y locales, es evidente que no puede haber afectación alguna del ámbito competencial privativo del Estado.» (FJ 69).

Se trata, por tanto, de que en estas modalidades o instrumentos de consulta popular no concurran los requisitos del referéndum (estos son, que se recabe la opinión del cuerpo electoral, que se sustancie mediante un procedimiento electoral y que verse sobre asuntos cuya gestión constituya el objeto del derecho fundamental a la participación política del art. $23 \mathrm{CE}$ ). Puesto que excede de los propósitos de este trabajo entrar en el estudio de la figura del referéndum así como su diferenciación de la figura de la consulta popular, sobre la distinción de ambas figuras nos remitimos a BUENO ARMIJO ${ }^{15}$.

b) Por otra parte, las «consultas populares celebradas por vía de referéndum», que son las que estaban contempladas en el art. 15.2 EAAnd 1981 y que actualmente están previstas en el art. 71 LBRL que,

14 BUENO ARMIJO, A. (2008a): "Competencias sobre consultas populares. En especial por vía de referéndum (Comentario al art. 78)", en MUÑOZ MACHADO, S. y REBOLLO PUIG, M. (dirs.): Comentarios al Estatuto de Autonomía para Andalucía. Pamplona: Aranzadi, págs. 784 y ss. Finalizada la redacción de este trabajo, se ha publicado la monografía de FERNÁNDEZ RAMOS, S. y PÉREZ MONGUIÓ, J. M. (2019): Vox populi: consultas populares y procesos participativos. Pamplona: Thomson Reuters Aranzadi, que incide directamente sobre la distinción entre las consultas referendatarias y no refendarias, aunque sólo he podido consultar el índice.

15 BUENO ARMIJO, A. (2008b): "«Consultas populares» y «referéndum consultivo»: una propuesta de delimitación conceptual y de distribución competencial”, en Revista de Administración Pública, núm. 177, págs. 203-213. También puede verse, PÉREZ SOLA, N. (2009): "La competencia exclusiva de las Comunidades Autónomas en materia de consultas populares", en Teoría y Realidad Constitucional, núm. 24, págs. 442-445, CARRASCO DURÁN, M. (2012): "Artículo 78. Consultas populares", en CRUZ VILLALÓN, P. y MEDINA GUERRERO, M. (dirs.): Comentarios Estatuto de Autonomía para Andalucía. Sevilla: Parlamento de Andalucía (Tomo II), págs. 1.284 y 1.286 y PÉREZ ALBERDI, M. R. (2018): "Referéndum y consultas populares", en TUDELA, J., CASTELLÁ, J. M., EXPÓSITO, E. y KÖLLING, M. (eds.): Libro Blanco sobre la calidad democrática en España. Madrid: Marcial Pons, págs. 222-225. 
REALA. Nueva Época - N. 13, abril-septiembre 2020 - ISSN: 1989-8975 - DOI: 10.24965/reala.i13.10741 - [Págs. 47-74]

Consultas populares y entidades locales: a propósito de la Ley 7/2017, de 27 de diciembre, de Participación Ciudadana de Andalucía

como se verá seguidamente, ha sido desarrollado por la Ley 2/2001. Las consultas reguladas por estos preceptos se han venido calificando por la doctrina como referéndum municipal, referéndum local o consultas populares referendatarias ${ }^{16}$. Incluso la STC 51/2017, de 10 de mayo de 2017 , que resuelve un recurso de inconstitucionalidad interpuesto en relación con la Ley del Parlamento de Cataluña 4/2010, de 17 de marzo, de consultas populares por vía de referéndum, habla de «referenda municipales» (entre otros, en los FFJJ 5.c) y 7). De acuerdo con lo anterior, el problema que se plantea respecto del art. 78 EAAnd 2007 es que su inciso final exceptúa el referéndum, que era el único ámbito sobre el que la Comunidad Autónoma tenía asumidas competencias previamente. No obstante, como ha dicho la doctrina a la que nos referimos someramente, esta exclusión no ha impedido que la Comunidad Autónoma tenga competencias sobre dicha materia ${ }^{17}$.

Segundo. A diferencia del art. 15.2 EAAnd 1981, que otorgaba a la Junta de Andalucía competencia de desarrollo legislativo, el art. 78 EAAnd 2007 atribuye una competencia exclusiva sobre un amplio catálogo de actuaciones que van en relación con los instrumentos de consulta indicados (establecimiento del régimen jurídico, modalidades, procedimiento, realización y convocatoria de las mismas). Ahora bien, este carácter exclusivo debe entenderse sin perjuicio de la competencia estatal relativa a las bases del régimen jurídico de las administraciones públicas del art. 149.1.18. ${ }^{\circ} \mathrm{CE}^{18}$

Tercero. El nuevo art. 78 EAAnd 2007 prescinde del término «local», que sí estaba expresamente contemplado por su precedente. Como señalan CARRASCO DURÁN y GÓMEZ FERNÁNDEZ, de esta supresión puede deducirse la intención del legislador autonómico de incluir tanto las consultas populares de ámbito local como de ámbito autonómico ${ }^{19}$.

\subsection{La Ley 2/2001 de consultas populares locales de Andalucía}

\subsubsection{Delimitación y ámbito de aplicación}

Tras veinte años de vigencia del EAAnd 1981 se aprobó la Ley 2/2001 que tomó como base el art. 15.2 del Estatuto andaluz vigente en aquel momento y el art. 71 LBRL, pues es sabido que en la Comunidad Autónoma no existe ley de régimen local. La Ley cuenta con veintisiete artículos -que quedan divididos en cuatro títulos-, tres disposiciones adicionales y tres disposiciones finales y ha sido desarrollada por el Decreto $298 / 2002$, de 10 de diciembre, que disciplina la organización y funcionamiento del Registro de Consultas Populares Locales de Andalucía (se da así cumplimiento al mandato de la disposición adicional primera de la Ley 2/2001 que ordena su creación). Del nombre que se le ha dado a la Ley o de su art. 1 que delimita su objeto de regulación (las «consultas populares locales») podría inferirse que regula las consultas populares en todas las entidades locales. Sin embargo, el articulado se refiere continuamente al municipio ${ }^{20}$. El único

16 Vid., entre otros, FONT I LLOVET, T. (1985: 125), PÉREZ SOLA, N. (1994): La regulación constitucional del Referéndum. Marmolejo (Jaén): Universidad de Jaén, pág. 130, ÁLVAREZ MONTOTO, J. (2009): "Las consultas populares en el ámbito local", en El consultor de los Ayuntamientos, núm. 2, pág. 194, BUENO ARMIJO, A. (2008a: 787), CARRASCO DURÁN, M. (2012: 1285), RIVERO YSERN, J. L. (2014: 137 y ss) y ORDUÑA PRADA, E. (2017): "Democracia local y participación ciudadana: nuevas perspectivas sobre consultas populares municipales", en Anuario de Gobierno Local, núm. 1, pág. 75.

17 BUENO ARMIJO, A. propone justificar la competencia sobre consultas populares celebradas por vía de referéndum acudiendo al título competencial de régimen local asumido en el art. 60 EAAnd 2007. De este modo la Junta de Andalucía conservaría su competencia sobre el desarrollo normativo en virtud de la competencia genérica en materia de régimen local, (2008a: 788-789). NARANJO DE LA CRUZ, R. plantea dos interpretaciones alternativas. La primera sería «interpretar el término "referéndum" en un sentido formal, de manera tal que el término se haga referir exclusivamente a las modalidades de referéndum previstas en la Constitución. De esta forma, la CA tendría competencia sobre cualquier consulta popular que pudiera celebrarse en su ámbito territorial y material de competencias». La segunda sería "vincular el inciso final ("con la excepción del referéndum"), no a todas las facultades enumeradas en el art. 78 EA, sino sólo a la última de las citadas, esto es, a la convocatoria, con lo que la CA lo único que no podría hacer en relación con un referéndum de ámbito autonómico sería convocarlo» (2009): "Capítulo II. Competencias (I)", en TEROL BECERRA, M. J. (dir.): Comentarios al Estatuto de Autonomía para Andalucía. Valencia: Tirant lo Blanch, págs. 199-200. En opinión de IBÁÑ̃EZ MACÍAS, A., el artículo lo que niega no es la competencia sobre referéndum, sino la competencia exclusiva sobre el mismo, por lo que puede deducirse que la titularidad de la competencia sobre referéndum es compartida, (2013): "Los referendos regional y local en el Estado autonómico. Sus bases y límites constitucionales", en Revista Vasca de Administración Pública, pág. 119.

18 Así ha sido destacado tanto por la doctrina, BUENO ARMIJO, A. (2008a: 785) y CARRASCO DURÁN, M. (2012: 1.292), como por la jurisprudencia (STC 31/2010, FJ 69).

19 CARRASCO DURÁN, M. (2012: 1.282 y 1.283) y GÓMEZ FERNÁNDEZ, V. M. (2012): “Art. 78. Consultas populares”, en ORTíz SÁNCHEZ, M. y CARRASCO LÓPEZ, I. (coords.): Comentarios al Estatuto de Autonomía para Andalucía. Sevilla: Instituto Andaluz de Administración Pública, pág. 541.

20 Muestra de esto es que solo pueden ser objeto de consulta los asuntos de «competencia propia municipal» (art. 2.1), que la consulta popular no puede menoscabar las «facultades de decisión que corresponden a los órganos representativos del municipio» 
REALA. Nueva Época - N.o 13, abril-septiembre 2020 - ISSN: 1989-8975 - DOI: 10.24965/reala.i13.10741 - [Págs. 47-74]

Consultas populares y entidades locales: a propósito de la Ley 7/2017, de 27 de diciembre, de Participación Ciudadana de Andalucía

Inmaculada Ruiz Magaña

precepto que habla de la «Entidad local convocante» es el art. 2.1. Frente al mismo caben dos interpretaciones. La primera, considerar que estos términos son equivalentes a municipio o, la segunda, entender que abre la puerta a que lo hagan otras entidades locales. Si bien, esta última no parece sustentarse en el contenido de la Ley. Todas estas afirmaciones llevan a concluir que la intención del legislador autonómico era normar solo las consultas populares municipales y excluir las de ámbito supramunicipal. Esta perspectiva encuentra apoyo en la LBRL y en la LO 2/1980 que también aluden a los municipios ${ }^{21}$.

La Ley define en el art. 2.1 la consulta popular local como un «instrumento de conocimiento de la opinión de los vecinos». Continúa el artículo indicando que los asuntos sobre los que puede versar son aquellos que sean i) de "competencia propia municipal», ii) de "carácter local» y iii) «de especial relevancia» para los intereses de los vecinos. Por tanto, la Ley andaluza no introduce ninguna particularidad que no se contenga ya en el art. 71 LBRL. Como límites materiales se excluyen aquellos asuntos que i) sean contrarios al ordenamiento jurídico, ii) que menoscaben las facultades de decisión que corresponden a los órganos representativos y iii) aquellas materias propias de la Hacienda local (apartados 2 y 3 del art. 2). Aunque, como sostiene NÚÑEZ LOZANO, difícilmente se podrán menoscabar las facultades de decisión que corresponden a los órganos representativos cuando el resultado de la consulta tiene carácter no vinculante ${ }^{22}$.

La consulta se decide por sufragio universal, libre, igual, directo y secreto, a ejercer por los electores que componen el cuerpo electoral (art. 3). Aclara el art. 15.1 que este último lo componen los vecinos del municipio que gocen del derecho de sufragio activo en las elecciones municipales ${ }^{23}$. Para FERNÁNDEZ RAMOS la LBRL (arts. 18.1 y 71) no es concluyente sobre quiénes pueden expresar su opinión en la consulta y, en consecuencia, entiende que se permite que los legisladores autonómicos puedan atribuir el derecho bien a los vecinos del municipio en general bien a aquellos que tengan derecho de sufragio activo en las elecciones municipales ${ }^{24}$. Se trata de una cuestión que no es baladí, pues como ha puesto de manifiesto CANO CAMPOS el derecho de sufragio activo en las elecciones municipales no está reconocido a todos los vecinos del municipio, ni todos los titulares de tal derecho son vecinos en el sentido del art. 15 LBRL (vecino es aquel que está inscrito en el Padrón municipal) ${ }^{25}$.

En lo que a lo que atañe a los efectos de la consulta, como ya se ha adelantado, la Ley establece que carece de vinculación jurídica para el municipio convocante (art. 2.1 Ley 2/2001). No obstante, esta no es una decisión que haya tomado autónomamente el legislador autonómico sino que el carácter no vinculante de las consultas ya se deduce del art. 69.2 LBRL (según este, las distintas formas de participación no pueden menoscabar las facultades de decisión que corresponden a los órganos representativos ${ }^{26}$. Algunos Regla-

(art. 2.2), que la circunscripción electoral es el «término municipal» (art. 5) o que la iniciación del procedimiento de consulta se pueda efectuar por la Corporación municipal (art. 6.1).

21 Así ha tenido ocasión de señalarlo NÚÑEZ LOZANO, M. C. (2001): "Las consultas populares locales", en Revista Andaluza de Administración Pública, núm. 42, págs. 435 y 436.

22 NÚÑEZ LOZANO, M. C. (2001: 432).

23 Según el art. art. 2 de la Ley Orgánica 5/1985, de 19 de junio, del Régimen Electoral General gozan del derecho de sufragio activo en las elecciones municipales los españoles mayores de edad que estén inscritos en el censo electoral. Añade el art. 176 de la misma Ley que también poseen este derecho los residentes extranjeros en España cuyos respectivos países permitan el voto a los españoles en dichas elecciones, en los términos de un tratado; así como todas las personas residentes en España que, sin haber adquirido la nacionalidad española: a) tengan la condición de ciudadanos de la Unión Europea según lo previsto en el párrafo 2 del apartado 1 del artículo 8 del Tratado Constitutivo de la Comunidad Europea o, b) reúnan los requisitos para ser elector exigidos para los españoles por la Ley 5/1985 y hayan manifestado su voluntad de ejercer el derecho de sufragio activo en España. Por su parte, el art. 17.5 LBRL también reconoce el derecho de sufragio en las elecciones municipales a los españoles residentes en el extranjero que estén inscritos en el Padrón (específico) de españoles residentes en el extranjero.

24 FERNÁNDEZ RAMOS, S. (2005): La información y participación ciudadana en la Administración Local. Barcelona: Bosch, págs. 276 y 277.

25 CANO CAMPOS, T., (2007): "Artículo 18", en REBOLLO PUIG, M. (dir.): Comentarios a la Ley Reguladora de las Bases del Régimen Local. Valencia: Tirant lo Blanch (Tomo I), pág. 366.

26 En esta línea, cabe traer a colación la Ley $12 / 2019$, de 12 de marzo, de consultas populares y procesos participativos de las Islas Baleares (BOE, núm. 89, de 13 de abril de 2019) que regula extensamente la figura del «referéndum municipal» en los arts. 10 al 36 y que, concretamente, en la redacción original del art. 10.3 disponía que «El resultado de este tipo de consulta, siempre y en todo caso, será vinculante para la autoridad convocante». La constitucionalidad de este último artículo y la de algunos más de la citada Ley (entre los que se encuentran los arts. 19 a 36) ha sido cuestionada por el Gobierno de la Nación y ha dado lugar al Acuerdo de la Comisión Bilateral de Cooperación Administración General del Estado-Comunidad Autónoma de las Islas Baleares en relación con la Ley 12/2019 para iniciar negociaciones. Este Acuerdo está publicado en la Resolución de 21 de junio de 2019 de la Secretaría General de Coordinación Territorial (BOE, núm. 169, de 16 de julio de 2019). Concluido el proceso las discrepancias han sido solventadas y, en lo que se refiere al art. 10.3, las Islas Baleares han asumido el compromiso de cambiar la redacción del precepto, cuyo tenor debe ser el siguiente: «El resultado de este tipo de consulta será vinculante para la autoridad convocante en los supuestos en que así se prevea en la legislación estatal», apartado I.b) de la Resolución de 17 de diciembre de 2019 (BOE, núm. 12, de 14 de enero de 2020). 
REALA. Nueva Época - N.o 13, abril-septiembre 2020 - ISSN: 1989-8975 - DOI: 10.24965/reala.i13.10741 - [Págs. 47-74]

Consultas populares y entidades locales: a propósito de la Ley 7/2017, de 27 de diciembre, de Participación Ciudadana de Andalucía

mentos de Participación Ciudadana (en adelante RPC) prevén que el resultado de la consulta popular sea tratado en sesión plenaria extraordinaria de la Corporación en la que esta adoptará el acuerdo teniendo en cuenta -junto con el objeto de la consulta y el resultado de la misma- «el porcentaje de participación». Es lo que ocurre con el RPC de Cádiz, de 30 de noviembre de 2017 (art. 44) ${ }^{27}$. Otra de las consecuencias que tiene la celebración de la consulta es que queda prohibido que el asunto tratado pueda ser sometido a una nueva consulta durante el tiempo que reste a la corporación municipal (art. 4.3 Ley 2/2001).

\subsubsection{Procedimiento}

a) Iniciativa. La iniciativa de la consulta puede ser instada por la propia Corporación municipal -mediante acuerdo adoptado por mayoría simple a propuesta de un grupo municipal- o por la solicitud de los vecinos que gocen de derecho de sufragio activo en las elecciones municipales (art. 6.1 y 3 ) $^{28}$. En este último caso, la petición debe reunir una serie de requisitos, estos son: i) estar suscrita únicamente por aquellos vecinos que gocen de derecho de sufragio activo en las elecciones municipales (art. 6.3); ii) contener la identificación de cada uno de ellos y su firma formalizada ante el Secretario de la Corporación u otro fedatario público (art. 6.2); iii) reunir un número mínimo de firmas que se determina de conformidad con los tramos de población del art. 6.1; y iv) designar un representante (art. 6.4). Recibida la solicitud en el registro del Ayuntamiento, el Alcalde es el encargado de adoptar las medidas procedentes para verificar que concurren los anteriores requisitos cuya certificación corresponde al Secretario de la corporación (cfr. apartados 1, 2 y 3 del art. 7). Seguidamente, y dentro del plazo de los treinta días desde la recepción de la solicitud en el Ayuntamiento, el Alcalde debe remitirlo al Pleno para su aceptación. Este no es el acuerdo de aceptación de la celebración de la consulta que requiere el art. 71 LBRL sino otro acuerdo previo que exige la Ley 2/2001 para aprobar la iniciativa. Como pone de relieve RODRÍGUEZ RODRÍGUEZ, nada dice el precepto sobre el quorum necesario para que la iniciativa se entienda aceptada, por lo que hay que entender en base a la regla general de los arts. 47.1 y 123.2 LBRL que la aprobación requiere la mayoría simple de los miembros presentes ${ }^{29}$.

b) Periodo de alegaciones. El art. 8 contempla como trámite adicional de participación ciudadana que, aceptada por el Pleno la solicitud vecinal o adoptado el acuerdo por la Corporación municipal, la iniciativa de consulta popular se someta en los cinco días siguientes a información pública, por un periodo no inferior a veinte días hábiles, a fin de que cualquier persona física o jurídica pueda efectuar las alegaciones que considere convenientes (art. 8) ${ }^{30}$. Para garantizar la publicidad y efectividad de su realización, dicho trámite se tiene que publicar en el BOJA y en el respectivo BOP. Igualmente, se ha de comunicar a la Delegación de Gobierno de la Junta de Andalucía en la provincia que corresponda para que en el plazo de quince días hábiles también pueda formular alegaciones.

c) Acuerdo del Pleno para solicitar la celebración de la consulta. El Pleno del Ayuntamiento debe «ponderar» las alegaciones presentadas y, «si procede», acordar por mayoría absoluta del número legal de miembros de la Corporación la celebración de la consulta popular (de esta forma el art. 9.2 Ley 2/2001 da cumplimiento a la exigencia del art. $71 \mathrm{LBRL})^{31}$.

En el caso de que acepte la celebración de la consulta popular el contenido del acuerdo ha de ajustarse a las exigencias del art. 9.2 Ley 2/2001. Su adopción implica la continuación del procedimiento tal y como se va a ver en el apartado siguiente.

27 BOP de Cádiz, núm. 247, de 29 de diciembre de 2017.

28 El RPC de Granada también admite que la iniciativa pueda ser instada por el Consejo Social de la Ciudad o por el Consejo de Participación Vecinal, art. 24 (BOP de Granada, núm. 160, 20 de agosto de 2004).

29 RODRÍGUEZ RODRÍGUEZ, J. L. (2001): “Una primera aproximación a la ley de regulación de las consultas populares locales en Andalucía 2/2001, de 3 de Mayo", en Revista de Estudios de la Administración Local y Autonómica, núm. 286-287, pág. 473.

30 GARCÍA GARCÍA, M. J. señala que al restringir la Ley 2/2001 el ejercicio del derecho a los vecinos del municipio que gocen del derecho de sufragio activo «no tiene sentido la apertura de la información pública, que amplía considerablemente el ámbito subjetivo de la iniciativa de consulta permitiendo que cualquier persona física o jurídica pueda efectuar las alegaciones que considere adecuados sobre la procedencia de la misma», (2009): "La celebración de consultas populares a petición de los vecinos", en Revista Vasca de Administración Pública, núm. 83, pág. 78.

31 Según la STSJ de Madrid 227/2012 de 20 febrero (recurso 945/2010) esta necesaria intervención «no responde sino a lo establecido por el art. 69.2 LBRL (según el cual "Las formas, medios y procedimientos de participación que las Corporaciones establezcan en ejercicio de su potestad de autoorganización no podrán en ningún caso menoscabar las facultades de decisión que corresponden a los órganos representativos regulados por la Ley"» (FJ 3). 
REALA. Nueva Época - N. 13, abril-septiembre 2020 - ISSN: 1989-8975 - DOI: 10.24965/reala.i13.10741 - [Págs. 47-74]

Consultas populares y entidades locales: a propósito de la Ley 7/2017, de 27 de diciembre, de Participación Ciudadana de Andalucía

Si por el contrario el Pleno estimase que procede denegar la solicitud debe hacerlo «mediante una resolución debidamente motivada» (FJ 6 de la Sentencia de la Audiencia Territorial de Sevilla de 14 de junio de 1988). La citada Sentencia -confirmada por la STS de 14 de noviembre de 1989 (Referencia Aranzadi: RJI198918304), que reproduce todos los fundamentos jurídicos de la anterior- resuelve el recurso contencioso-administrativo interpuesto ante la desestimación por silencio administrativo de la petición dirigida al Alcalde de Sevilla en petición una consulta popular relativa a las obras del metro de la ciudad. La Sala indica que la solicitud de celebración de una consulta del art. 18.1.f) LBRL «se trata del ejercicio de un derecho público subjetivo, y de la formulación de una auténtica reclamación que en consecuencia debe ser objeto de una contestación» (FJ 6, que va en relación con el FJ 4). Por tanto, «la denegación aún a través de la fórmula del silencio administrativo negativo, puede ser objeto de la necesaria revisión jurisdiccional, dentro del amplio marco que constituye el artículo 106.1 de la Constitución» (FJ 6).

Para BARATA I MIR esta decisión del Pleno es «ciertamente política». El autor defiende que la decisión va a depender de que el Gobierno municipal detecte la necesidad de acudir a la consulta directa de la ciudadanía. Es decir, que «considere (...) inadecuado para los intereses municipales la utilización de un criterio político formado exclusivamente en el seno de aquéllos» (órganos representativos municipales) ${ }^{32}$. Por su parte, GARCÍA GARCÍA considera que no hay margen para la discrecionalidad y que solamente puede denegarse válidamente si la iniciativa adolece de los requisitos legales establecidos ${ }^{33}$. Sin perjuicio de lo anterior, hay que tener presente que, como ha señalado la STSJ de Navarra 917/2001 de 22 de junio (recurso 395/2001), las consultas populares están previstas como una «mera posibilidad», es decir, se trata de «facultad que se otorga a los Alcaldes para realizarla, si lo estiman conveniente» (FJ 5). El art. 71 LBRL establece expresamente que «podrán» someter a consulta. Por tanto, el hecho de que se reúna el número de firmas requerido no significa que el procedimiento tenga que seguir obligatoriamente adelante.

d) Tramitación de la preceptiva autorización y acuerdo del Gobierno de la Nación. Acordada la celebración de la consulta, el Alcalde debe remitir una certificación literal del acuerdo favorable del Pleno junto con una copia del expediente a la «Consejería de Gobernación» (art. 10 Ley 2/2001). En la actualidad, las competencias de la antigua Consejería de Gobernación corresponden a la Consejería de Turismo, Regeneración, Justicia y Administración Local (por esta razón en adelante nos referiremos a esta última) ${ }^{34}$. Dicha solicitud es tramitada a través de la Presidencia de la Junta de Andalucía que la envía junto con un informe, en un plazo no superior a veinte días hábiles desde la recepción del acuerdo del Pleno, al Gobierno de la Nación para su autorización. Este trámite, exigido por el art. 71 LBRL, es fundamental y su omisión supondría contrariar la legalidad. Precisamente, el RPC de Barcelona, de 6 de octubre de 2017, que regulaba la figura de las «consultas ciudadanas» (arts. 14 y 69 a 96) ha sido anulado por la STSJ de Cataluña de 25 de octubre de 2019 (recurso 411/2017) ${ }^{35}$. Entre otras razones, esto se debe a que el RPC referenciado solo preveía la aprobación de la iniciativa ciudadana por parte del Consejo Municipal omitiendo toda referencia a la necesidad de recabar la autorización del Gobierno de la Nación. A juicio de la Sala esta regulación «permitiría la convocatoria de la consulta sin solicitar tal preceptiva autorización» (FJ 5), apartándose así de la LBRL.

Una vez adoptado el acuerdo por el Gobierno de la Nación sobre la procedencia de la celebración de la consulta, la Presidencia de la Junta de Andalucía debe, dentro de los cinco días hábiles desde su recepción, dar traslado del mismo a la Consejería de Turismo, Regeneración, Justicia y Administración Local para su remisión al municipio afectado en los dos días siguientes. Como se verá seguidamente, si el acuerdo autoriza la celebración de la consulta el siguiente paso es la convocatoria. En cambio, si el acuerdo deniega la celebración de la consulta, la entidad solicitante puede recurrir dicha decisión interponiendo recurso

32 BARATA I MIR, J. (1999): Los actos de gobierno en el ámbito municipal. Madrid: Tecnos, págs. 196 y 197.

33 GARCÍA GARCÍA, M. J. (2009: 77-78). En igual sentido, FERNÁNDEZ RAMOS, S. (2007: 1.826), RIVERO YSERN, J. L. (2014: 138) y ROBLES MIGUEL, C. (2014): "Disposición adicional”, en DELGADO-IRIBARREN GARCÍA-CAMPERO, M. (coord.), Comentarios a la Ley Orgánica del Régimen Electoral General y a la Ley Orgánica de Referéndum. Madrid: La Ley, pág. 1.899.

34 Las competencias de la Consejería de Gobernación en materia de Administración Local han sido asumidas, sucesivamente, por las siguientes consejerías: la Consejería de Gobernación y Justicia (art. 2.1 del Decreto del Presidente 14/2010, de 22 de marzo), la Consejería de Administración Local y Relaciones Institucionales (art. 4.1 del Decreto del Presidente 3/2012, de 5 de mayo), la Consejería de la Presidencia y Administración Local (art. 3.1 del Decreto de la Presidenta 12/2015, de 17 de junio), la Consejería de Presidencia, Administración Local y Memoria Democrática (art. 3.1 Decreto de la Presidenta 12/2017, de 8 de junio) y actualmente por la Consejería de Turismo, Regeneración, Justicia y Administración Local (art. 3.1 del Decreto del Presidente 2/2019, de 21 de enero modificado por el Decreto del Presidente 6/2019, de 11 de febrero y art. 1.e) del Decreto 99/2019, de 12 de febrero, por el que se establece la estructura orgánica de la Consejería de la Presidencia, Administración Pública e Interior).

35 BOP de Barcelona de 30 de octubre de 2017. 
REALA. Nueva Época - N.o 13, abril-septiembre 2020 - ISSN: 1989-8975 - DOI: 10.24965/reala.i13.10741 - [Págs. 47-74]

Consultas populares y entidades locales: a propósito de la Ley 7/2017, de 27 de diciembre, de Participación Ciudadana de Andalucía

contencioso-administrativo ante la Sala de lo Contencioso-Administrativo del Tribunal Supremo (art. 12.1.a) Ley 29/1998, de 13 de julio, reguladora de la Jurisdicción Contencioso-Administrativa). En Andalucía, hasta la fecha, se ha recurrido el acuerdo denegatorio del Gobierno de la Nación en tres ocasiones. Se exponen sintéticamente a continuación los pronunciamientos del Tribunal Supremo.

1. La STS $1205 / 2000$ de 17 de febrero (recurso 404/1998) desestima el recurso contencioso-administrativo interpuesto por el Ayuntamiento de Algeciras (Cádiz) contra el acuerdo del Consejo de Ministros que deniega la autorización para la convocatoria de una consulta popular consistente en la articulación del municipio de Algeciras y de su entorno comarcal en una novena provincia andaluza. Entiende la Sala que el asunto tiene carácter supralocal al afectar al ámbito territorial de la provincia de Cádiz y a las competencias propias de su Diputación provincial, que no puede ver mermada su integridad territorial sino a través de una Ley Orgánica (FJ 6).

2. La STS 4930/2008 de 23 de septiembre (recurso 474/2006) estima el recurso contencioso-administrativo interpuesto por el Ayuntamiento de Almuñécar (Granada) contra el acuerdo del Consejo de Ministros que rechaza autorizar la celebración de una consulta popular referida a la aprobación inicial del Plan General de Ordenación Urbanística (PGOU) y declara su nulidad. Arguye el Tribunal Supremo que la decisión del Consejo de Ministros -basada en que no concurría el requisito de que el asunto fuese de competencia propia municipal- realiza una interpretación contra legem del art. 71 LBRL. Pues, identifica indebidamente el concepto de «asuntos de la competencia propia municipal» a que alude dicha disposición legal con «asuntos de la competencia exclusiva del municipio», sin hacer una lectura armonizada del 25.2 d) LBRL y del art. 3 de la Ley 7/2002, de 27 de diciembre de Ordenación Urbanística de Andalucía, de los cuales se desprende que la aprobación de un PGOU se corresponde con el ejercicio de una competencia propia municipal que se ejerce en régimen de autonomía y bajo la propia responsabilidad (FJ 2).

3. La STS 2526/2016 de 29 de noviembre (recurso 603/2015) desestima el recurso contencioso-administrativo interpuesto por el Ayuntamiento de Cogollos Vega (Granada) contra el acuerdo del Consejo de Ministros. Este deniega la autorización para la celebración de una consulta popular a los vecinos sobre el mantenimiento de la concesión otorgada a una empresa para la gestión de los servicios del ciclo integral del agua del municipio, ya acordada por un convenio suscrito por el anterior Alcalde, hasta el año 2027 sin acuerdo del Pleno. Explica la Sentencia que la consulta no tiene por objeto un asunto propio de competencia municipal, como exige el art. $71 \mathrm{LBRL}$, sino que solo guarda una relación indirecta con un servicio público contenido en el listado del art. 25.2.c) LBRL (FJ 5).

e) Convocatoria. Recibida la comunicación del otorgamiento de la autorización corresponde al Alcalde convocar en los tres días hábiles siguientes la consulta popular -como es sabido, la delegación de esta atribución queda prohibida por el art. 43.1 del Real Decreto 2568/1986, de 28 de noviembre, por el que se aprueba el Reglamento de Organización, Funcionamiento y Régimen Jurídico de las Entidades Locales (en adelante ROF)-. La convocatoria adopta la forma de decreto (cuyo contenido ha de ajustarse a lo dispuesto por el art. 11.1 Ley 2/2001) y se publica en el BOJA, en el BOP, en uno de los medios de comunicación de mayor difusión en el ámbito local correspondiente y en el tablón de edictos del Ayuntamiento. En este sentido, recuérdese que el deber de las corporaciones locales de facilitar información sobre su actividad así como la participación de los ciudadanos en la vida local está recogido en el art. 69.1 LBRL.

La consulta presenta una serie de restricciones temporales. Así, no puede ser convocada ni tener lugar en los periodos que median entre la convocatoria y celebración de: a) elecciones de Diputados y Senadores a Cortes Generales, al Parlamento de Andalucía, de los miembros de las Entidades Locales o de los Diputados del Parlamento Europeo o, b) de un referéndum, cuando estos se efectúen en el ámbito territorial afectado por la consulta popular local (art. 4.1). La Ley contempla incluso una «desconvocatoria» de la consulta ${ }^{36}$. Es decir, si esta ya hubiese sido convocada y posteriormente se convocan las elecciones o referéndum a los que se ha hecho referencia, la convocatoria queda sin efecto debiendo ser convocada nuevamente (art. 4.2).

f) La continuación del procedimiento. Los arts. 12 y ss. concretan aspectos atinentes a la Administración Electoral, el cuerpo electoral, las secciones electorales, sus locales y las Mesas electorales corres-

36 RODRÍGUEZ RODRÍGUEZ, J. L. (2001: 466). 
REALA. Nueva Época - N. 13, abril-septiembre 2020 - ISSN: 1989-8975 - DOI: 10.24965/reala.i13.10741 - [Págs. 47-74]

Consultas populares y entidades locales: a propósito de la Ley 7/2017, de 27 de diciembre, de Participación Ciudadana de Andalucía

Inmaculada Ruiz Magaña

pondientes a cada una de ellas. Del desarrollo del procedimiento se ocupan los arts. 19 a 27 (campaña de información, documentos oficiales, voto anticipado y votación y escrutinio). La disposición final primera se remite en todo lo no previsto por la propia Ley 2/2001 a la Ley 1/1986, de 2 de enero, Electoral de Andalucía, que se debe aplicar «teniendo en cuenta su adaptación a las características y ámbito de la consulta».

\subsection{Utilización práctica en Andalucía}

Expuesto todo lo anterior, resulta interesante conocer la realidad práctica de las consultas populares en Andalucía. Para la elaboración de este apartado se ha utilizado la información proporcionada por el Gobierno de la Nación con ocasión de la solicitud de información del Senador D. Jon Iñarritu García sobre las consultas populares autorizadas y rechazadas por el Consejo de Ministros ${ }^{37}$. El 27 de abril de 2018 el Gobierno dio respuesta a dicha solicitud con remisión de un documento Anexo, publicado en la sede electrónica del Senado, en el que aparecen las consultas populares promovidas en todo el territorio nacional desde 1985 hasta parte de 2018 (con indicación de: fecha, entidad solicitante, provincia, asunto sobre el que trata la consulta y situación -esto es, si ha sido autorizada o desautorizada por el Gobierno de la Nación, archivada o desistida- $)^{38}$. Según los datos, desde 1985 hasta 2017, en el ámbito estatal se ha promovido la celebración de 168 consultas populares. De estas, 54 han sido autorizadas, 77 no autorizadas, 24 archivadas y 13 desistidas. En Andalucía estos datos se corresponden con lo siguiente:

\begin{tabular}{lccccc}
\hline $\begin{array}{l}\text { Consultas populares promovidas } \\
\text { en Andalucía }\end{array}$ & Autorizadas & No autorizadas & Archivadas & Desistidas & Total \\
\hline Desde 1985 hasta 2000 & 3 & 8 & 2 & 1 & 14 \\
\hline Desde 2001 hasta 2017 & 4 & 3 & 1 & - & 8 \\
\hline
\end{tabular}

Fuente: elaboración propia a partir de los datos procedentes del Anexo remitido por el Gobierno de la Nación, ya referenciado.

Tal y como puede observarse en la tabla, la figura de las consultas populares tiene un alcance limitado: con carácter previo a la Ley 2/2001 se han promovido un total de catorce consultas populares (esto es, en un periodo de quince años) frente a las ocho iniciativas que se han impulsado desde que entró en vigor la Ley 2/2001 hasta 2017 (esto es, en un periodo de dieciséis años). Los resultados de este segundo periodo son realmente bajos de por sí pero además muestran un retroceso respecto del tramo anterior (es decir, en un lapso de tiempo algo mayor las consultas promovidas se han reducido casi a la mitad). La situación no deja de ser paradójica pues se supone que la existencia de una Ley en la materia va a incentivar el ejercicio del derecho y no al contrario, aunque en realidad la norma no menciona en ningún punto tener por finalidad promover el ejercicio del derecho ni fomentar una cultura participativa. No obstante, lo cierto es que la práctica inoperante de las consultas populares no es nada nuevo. Esta circunstancia ha sido puesta de manifiesto por la doctrina en reiteradas ocasiones y se ha asociado a la rígida interpretación de los requisitos legalmente exigidos ${ }^{39}$.

Al margen de lo anterior, teniendo en cuenta que la Ley 2/2001 ordena la creación del Registro de Consultas Populares Locales de Andalucía (en adelante, el Registro) y a fin ampliar los datos para la realización de este trabajo, el 30 de mayo de 2019 me dirigí a la Junta de Andalucía y, con apoyo en la Ley 19/2013, de 9 de diciembre, de Transparencia, Acceso a la Información Pública y Buen Gobierno (arts. 12 y 17) y en la Ley 1/2014, de 24 de junio, de Transparencia Pública de Andalucía (art. 7 apartado b), solicité la informa-

37 En concreto, la pregunta formulada era la siguiente: «¿Cuáles son todas y cada una de las consultas populares autorizadas y rechazadas por el Consejo de Ministros desde 1979? (especificando cuál era el motivo sobre el que se deseaba preguntar en cada una de las consultas)». [17-05-2019] Disponible en web: http://www.senado.es/web/expedientdocblobservlet?legis=12\&id=102375.

38 [17-05-2019] Disponible en web: http://www.senado.es/web/expedientdocblobservlet?/egis=12\&id=110690 y http://www.senado.es/web/expedientappendixblobservlet?legis=12\&id1=108267\&id2=1. Probablemente habrá habido otros intentos de promover la celebración consultas populares que no hayan prosperado y hayan quedado en el ámbito municipal.

39 Entre otros, FONT I LLOVET, T. (1985: 127), SÁNCHEZ MORÓN, M. (1992): "El sistema político local: fórmulas de gobierno y participación de la ciudadanía", en AA.VV., Informe sobre el Gobierno Local. Madrid: Ministerio para las Administraciones Públicas, pág. 318, FERNÁNDEZ RAMOS, S. (2005: 273), ORDUÑA PRADA, E. (2017: 87 y 88), MARTíNEZ ALONSO-CAMPS, J. L. (2010): "Las consultas populares municipales: consideraciones sobre el marco normativo y su identificación como referéndum", en Anuario del Gobierno Local, pág. 450 y RUIZ-RICO RUIZ, C. (2017): Reforma de la Administración Local y problemática jurídico-constitucional. Experiencias de innovación democrática. Valencia: Tirant lo Blanch, pág. 105. 
ción de «carácter público» contenida en dicho Registro (este carácter público se reconoce en el art. 5.1 del Decreto 298/2002, ya referenciado, que lo regula) ${ }^{40}$. El 9 de julio se respondió a mi solicitud con remisión de un documento cuyo encabezamiento reza "Consultas populares celebradas en Andalucía" (se acompaña este documento como Anexo. "Consultas populares celebradas en Andalucía" al final de este trabajo). Según estos datos, en dicho Registro solo están inscritas tres consultas populares. Son las celebradas en 2002 en Montellano (Sevilla), en 2009 en Almuñécar (Granada) y en 2014 en Galaroza (Huelva) ${ }^{41}$. Ante el desconcierto por la contradicción entre esta información y la facilitada por el Gobierno de la Nación (según la cual en Andalucía se han promovido ocho consultas populares desde 2001 hasta 2017), el 12 de julio de 2019 me dirigí nuevamente a la Junta de Andalucía y solicité información más precisa al respecto, tratando de aclarar si se trataba de un malentendido. En su contestación, del 1 de agosto de 2019, me comunicaron que «no existen más datos que los que se les adjunta a la interesada». Sorprende esta discordancia en un tema cuyo control y registro debe ser relativamente sencillo teniendo en cuenta el escaso número de consultas que se promueven. Además, se tiene constancia de que se ha celebrado alguna consulta popular, previamente autorizada por el Gobierno de la Nación, que no figura inscrita en el Registro. Es el caso de la consulta popular que tuvo lugar el 17 de abril de 2016 en el municipio de Los Barrios (Cádiz) ${ }^{42}$.

\section{CONSULTAS LOCALES Y PARTICIPACIÓN CIUDADANA EN LA LEY 7/2017}

\subsection{Generalidades}

\section{a) Objeto y ámbito de aplicación}

Como se ha tenido ocasión de ver, el EAAnd 2007 presta especial atención por profundizar en la participación ciudadana y, en lo que a las consultas populares se refiere, mediante el art. 78 amplía el concepto de consulta popular que contenía el EAAnd 1981 e introduce otros instrumentos de consulta. Recientemente, haciendo uso de estas competencias, desde la Comunidad Autónoma se vuelven a impulsar técnicas diversas de participación y consulta a los ciudadanos enmarcadas en la Ley $7 / 2017^{43}$. La Ley tiene por objeto según su art. 1.1.:

«(...) la regulación del derecho de participación ciudadana en la dirección de los asuntos públicos autonómicos y locales en Andalucía, en condiciones de igualdad, de manera real y efectiva, ya sea directamente o a través de las entidades de participación ciudadana en las que se integre la ciudadanía, así como el fomento de su ejercicio, en el marco de lo establecido en la Constitución, el Estatuto de Autonomía y los tratados comunitarios».

Con este propósito la Ley se compone de sesenta y seis artículos -estructurados en seis títulos, algunos divididos en capítulos y secciones- una disposición adicional, una disposición derogatoria y tres disposicio-

40 Como se ha indicado anteriormente, la disposición adicional primera de la Ley 2/2001 ordena la creación de un Registro que ha sido desarrollado por el Decreto 298/2002. El Registro, que está operativo desde el 11 de diciembre de 2002 , tiene por objeto «facilitar el seguimiento y control administrativo mediante la inscripción de las solicitudes presentadas, las que hayan sido autorizadas y los resultados de aquellas que se hayan celebrado» (art. 1.2). Asimismo cfr. art. 3 («Datos inscribibles»).

41 En general los porcentajes de participación de la ciudadanía en estas consultas no han sido demasiado altos; se corresponden con las siguientes cifras (calculadas en base al número de electores y número de votantes que figuran en el Anexo. "Consultas populares celebradas en Andalucía”. En Montellano un 68'33\% (la consulta versaba sobre la incorporación del municipio al consorcio de aguas de Huesna). En Almuñécar un 32'44\% (se preguntaba a los vecinos si respaldaban el acuerdo del Pleno del Ayuntamiento de aprobar inicialmente el plan general de ordenación urbanística del municipio). En Galaroza un 56'24\% (el texto consultaba a los vecinos si querían que el municipio recuperase el servicio de abastecimiento de agua transferido en ese momento a la mancomunidad de servicios de la provincia y se gestionase por Giahsa -sociedad mercantil-).

42 Vid. pág. 7 del documento proporcionado por el Gobierno de la Nación (ya referenciado) y la web del Ayuntamiento del Municipio en la que se ofrece información sobre los resultados finales, número de votos y porcentaje de participación. [12-07-2019]. Disponible en web: http://www.losbarrios.es/consulta-popular/.

43 De esta forma, Andalucía se suma a otras Comunidades Autónomas que disponen de leyes de participación ciudadana como Canarias (Ley 5/2010, de 21 de junio), Cataluña (Ley 10/2014, de 26 de septiembre), Castilla y León (Ley 3/2015, de 4 de marzo), Aragón (Ley 8/2015, de 25 de marzo), Valencia (Ley 2/2015, de 2 de abril), Galicia (Ley 7/2015, de 7 de agosto), País Vasco (Ley 2/2016, de 7 de abril), Baleares (Ley 12/2019, de 12 de marzo), la Comunidad Foral de Navarra (Ley Foral 12/2019, de 22 de marzo). o la Comunidad Autónoma de Castilla-La Mancha (Ley 8/2019, de 13 de diciembre). Por su parte, La Rioja ha iniciado la tramitación parlamentaria para aprobar una ley en la materia si bien en este caso no ha prosperado al caducar la iniciativa (BO del Parlamento de La Rioja, núm. 283, de 25 de mayo de 2019). 
REALA. Nueva Época - N.o 13, abril-septiembre 2020 - ISSN: 1989-8975 - DOI: 10.24965/reala.i13.10741 - [Págs. 47-74]

Consultas populares y entidades locales: a propósito de la Ley 7/2017, de 27 de diciembre, de Participación Ciudadana de Andalucía

nes finales. En síntesis, el Título I, "Disposiciones generales" recoge las bases y principios que rigen la interpretación del contenido de la norma; el Título II, "Derechos y obligaciones" delimita los sujetos legitimados para el ejercicio del derecho de participación ciudadana y las obligaciones de las Administraciones públicas respecto al mismo; el Título III, "Procesos de participación ciudadana" desarrolla diversas modalidades de participación encaminadas a facilitar el ejercicio del derecho; el Título IV, "Medidas de fomento de la participación ciudadana" contempla medidas destinadas a instaurar una cultura participativa en el conjunto de la sociedad, entidades e instituciones andaluzas; el Título V, "Organización administrativa de la participación ciudadana" contiene unas reglas a tener en cuenta a efectos organizativos de la Administración de la Junta de Andalucía y de las Administraciones locales andaluzas; y por último, el Título VI, "Sistema público de participación digital" se ocupa del desarrollo normativo de las nuevas tecnologías de la información y la comunicación. Lo expuesto hasta el momento ya permite deducir la amplísima regulación que contiene. Como seguidamente se podrá comprobar, con el fin de desarrollar el derecho de participación ciudadana se regulan distintos procedimientos y canales de participación que comprenden los ámbitos autonómico y local, de contornos no siempre claramente perfilados. De ahí que no sea en todos los casos fácil extraer en términos jurídicos conclusiones claras.

Se ha indicado que el objeto de la Ley 7/2017 es la regulación de la participación ciudadana. Por una parte, el art. 1.2 aclara que esta comprende «en todo caso, el derecho a participar plenamente en las decisiones derivadas de las funciones de gobierno y administración de la Comunidad Autónoma y las entidades locales andaluzas». Y, por otra parte, el art. 3.1 establece con carácter general un amplio ámbito de aplicación de la Ley: «se refiere al ejercicio de las competencias de gobierno y administración de la Comunidad Autónoma y de las entidades locales de Andalucía». Aunque no procede entrar aquí detalladamente en ello, pues este trabajo se centra en las consultas populares locales, sí conviene poner de manifiesto que el legislador se podría haber planteado hacer una distinción entre el gobierno y la administración de la Junta de Andalucía. Evidentemente hay que entender que estos términos no pueden equipararse al Gobierno y a la Administración de la Comunidad Autónoma en un sentido estricto. Este amplio concepto podría dar lugar a que los ciudadanos pudiesen expresar su opinión y participar, por ejemplo, en las atribuciones del Presidente de la Junta de Andalucía, entre las que se encuentra fijar las directrices de la acción de gobierno o nombrar y separar a los Vicepresidentes y Consejeros (art. 10 Ley 6/2006, de 24 de octubre, del Gobierno de la Comunidad Autónoma de Andalucía $)^{44}$. En lo que respecta a los entes locales, no cabe hablar de participación en las funciones de gobierno y administración. Es sabido que en estos entes territoriales no hay poder legislativo ni judicial y por eso no tiene sentido hablar de poder ejecutivo local. En los entes locales toda su organización es su administración y por eso se tiende a identificar, aunque no sea exacto, ente local y Administración local. A su vez, como en los municipios su organización administrativa es normalmente su respectivo Ayuntamiento (salvo los casos de concejo abierto), se suele identificar municipio y Ayuntamiento, pero realmente el Ayuntamiento es solo organización administrativa del municipio ${ }^{45}$. Como pone de relieve REBOLLO PUIG en el Prólogo de los Comentarios a la Ley Reguladora de las Bases del Régimen Local, «los entes locales son ante todo y sobre todo Administraciones públicas». Y, esto debe enfatizarse «(...) frente a algunas opiniones, tan erróneas como peligrosas, que ya no ven en los entes locales Administraciones ni en su estructura órganos administrativos, sino extrañas entelequias en las que se habla de división de poderes, de sistema parlamentario o presidencial y cosas por el estilo con las que se confunde todo y por completo hasta llegar a conclusiones aún más equivocadas» ${ }^{46}$.

Las disposiciones legales son de aplicación a la Administración de la Junta de Andalucía (incluidos sus órganos superiores de gobierno); a las agencias de la Administración de la Junta de Andalucía así como a las entidades de derecho público a las que hace referencia la disposición adicional segunda de la Ley 9/2007, de 22 de octubre, de la Administración de la Junta de Andalucía; a las entidades que integran la Administración local andaluza; y a los entes instrumentales de derecho público vinculados o dependientes de las Adminis-

44 Con posterioridad a la Ley $7 / 2017$, la Norma Foral 5/2018, de 12 de noviembre, sobre Participación Ciudadana de la Diputación Foral de Guipúzcoa utiliza términos similares a los de la Ley andaluza, aunque tampoco hace mayor aclaración. Así, marca como objeto la regulación del «derecho de participación (...) en el ejercicio por la Diputación Foral de la función de gobierno y administración, en el ámbito de las competencias forales» (art. 1.1) e incluye en su ámbito objetivo de aplicación el ejercicio de las competencias de gobierno y administración (art. 2.1).

45 REBOLLO PUIG, M. (2017b): "Derecho Administrativo y Administración Pública”, en REBOLLO PUIG, M. y VERA JURADO, D. (dirs.): Derecho Administrativo. Madrid: Tecnos (Tomo I), pág. 46.

${ }_{46}$ REBOLLO PUIG, M. (2007): "Prólogo", en REBOLLO PUIG, M. (dir.): Comentarios a la Ley de las Bases del Régimen Local. Valencia: Tirant lo Blanch, pág. 10. 
REALA. Nueva Época - N.o 13, abril-septiembre 2020 - ISSN: 1989-8975 - DOI: 10.24965/reala.i13.10741 - [Págs. 47-74]

Consultas populares y entidades locales: a propósito de la Ley 7/2017, de 27 de diciembre, de Participación Ciudadana de Andalucía Inmaculada Ruiz Magaña

traciones locales andaluzas (art. 3.2). Las Administraciones públicas andaluzas deben asumir una serie de obligaciones relativas a la participación ciudadana que están contenidas en el art. 9.

\section{b) Fines}

Entre los fines de la Ley, el art. 2 se refiere a promover la participación e instaurar una cultura participativa en la ciudadanía y en el funcionamiento de las Administraciones públicas andaluzas así como a fomentar la participación social de determinados colectivos (con este alcance hace concreta alusión a las mujeres, los menores de edad, las personas mayores y las personas que estén en situación de vulnerabilidad) y fortalecer la comunicación entre el gobierno y la ciudadanía ${ }^{47}$. De este modo, considera que las políticas públicas podrán beneficiarse de la riqueza de los conocimientos y experiencias de los vecinos.

Asimismo, incluye entre sus fines favorecer la colaboración entre la Administración autonómica y la local en el fomento de la participación y en la realización de procesos de participación en sus actividades de gobierno y administración, haciendo especial mención en el art. 2.i) Ley 7/2017 a los convenios de cooperación previstos en el art. 83 de la Ley 5/2010, de 11 de junio, de Autonomía Local de Andalucía (en adelante LAULA). En relación con esto último, habría que entender que lo pretendido por la Ley 7/2017 es que se trate de convenios de cooperación que tengan por objeto la participación ciudadana. Resulta llamativo que a pesar de ser una Ley que regula las relaciones entre Administración y administrados se ocupe también de las relaciones interadministrativas. Este propósito no queda en una declaración de intenciones pues el art. 9.e) Ley 7/2017 acoge de nuevo la idea y ordena a las Administraciones públicas andaluzas «impulsar la suscripción de convenios y acuerdos con otras Administraciones públicas» (en igual sentido, art. 51.2.h). Del mismo modo, el art. 9.e) también impulsa la elaboración de convenios con entidades públicas o privadas «especialmente con organizaciones no gubernamentales y entidades de voluntariado, en los términos previstos en la legislación aplicable» (en la misma línea los arts. 51.2.g) y 59) ${ }^{48}$.

\section{c) Procedimientos de participación ciudadana}

El Título III de la Ley 7/2017 está dedicado a los "Procesos de participación ciudadana" (a pesar de que la Ley habla de "procesos», en adelante nos referiremos a los mismos como «procedimientos» por considerar este último término más adecuado). Este es el Título más extenso y contiene cuarenta artículos (arts. 10 al 50). Según el art. 10 son procedimientos de participación «(...) el conjunto de actuaciones, procedimientos e instrumentos ordenados y secuenciados en el tiempo, desarrollados por las Administraciones públicas andaluzas en el ámbito de sus competencias, para posibilitar el ejercicio del derecho de la ciudadanía a la participación (...) en la dirección y gestión de los asuntos públicos autonómicos y locales». El legislador andaluz ha considerado que tienen tal carácter los citados en el art. 12 que deben entenderse, en un principio, como modalidades diferenciadas. Estos son:

«a) Deliberación participativa.

b) Participación ciudadana en la elaboración de presupuestos.

c) Participación ciudadana mediante consultas populares.

d) Participación ciudadana en la proposición de políticas públicas y elaboración de normas.

e) Participación ciudadana en el seguimiento y evaluación de las políticas públicas y de la prestación de los servicios públicos».

47 Corresponde aquí resaltar que la Ley $7 / 2017$ acorde con su art. 1.1, que declara como objeto regular el derecho de participación «en condiciones de igualdad (...)», atribuye al principio de igualdad de género un carácter «básico» para la norma y «fundamental» en los procesos de participación ciudadana (arts. 4.h y 52.3, respectivamente). En esta misma línea ya se había pronunciado la Ley 12/2007, de 26 de noviembre, para la promoción de la igualdad de género en Andalucía (arts. 5 y 53 al 56). Haciendo referencia no tanto a la participación desde la perspectiva de género como al principio de igualdad efectiva de mujeres y hombres en el derecho administrativo y en el acceso a la jurisdicción contencioso-administrativa puede verse DE LA TORRE MARTíNEZ, L. (2015): "La legitimación activa del «interés difuso»: ¿una nueva categoría para proteger la igualdad?", en Revista General de Derecho Administrativo, núm. 40, págs. 1-40.

48 Respecto de las entidades de voluntariado debe señalarse que la Ley 4/2018, de 8 de mayo, Andaluza del Voluntariado regula en el Título VI, "De la participación" el derecho de participación de las entidades de voluntariado en el diseño y ejecución de las políticas públicas de las áreas en que desarrollen sus actividades (art. 24.1). Aunque esta Ley es reciente, el derecho de participación ya se contemplaba en los arts. 24 y 25 de la derogada Ley 7/2001, de 12 de julio, del Voluntariado de Andalucía. 
REALA. Nueva Época - N.o 13, abril-septiembre 2020 - ISSN: 1989-8975 - DOI: 10.24965/reala.i13.10741 - [Págs. 47-74]

Consultas populares y entidades locales: a propósito de la Ley 7/2017, de 27 de diciembre, de Participación Ciudadana de Andalucía

Ya se ha avanzado que este trabajo se centra en los procedimientos de participación ciudadana mediante consultas populares. No obstante, sobre este precepto, puede señalarse que en principio de su literalidad no parece colegirse que regule procedimientos de participación que presenten gran novedad. Algunas son técnicas de participación de sobra conocidas. Se pueden indicar algunos ejemplos. En el ámbito de la Junta de Andalucía, la participación ciudadana en el seguimiento y evaluación de las políticas públicas «a través de los correspondientes órganos colegiados sectoriales de participación» del art. 31.1 se trata de una participación orgánica a la que ya se refirió en 1977 el Profesor GARCÍA DE ENTERRÍA ${ }^{49}$; y, la participación en los procedimientos de elaboración de leyes y reglamentos prevista en el art. 28 Ley $7 / 2017$ ya se aborda en el art. 133 de la Ley 39/2015, de 1 de octubre, del Procedimiento Administrativo Común de las Administra-

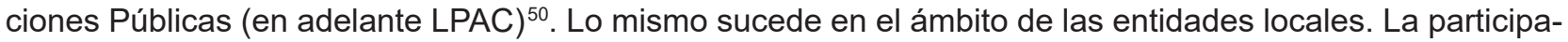
ción en los procedimientos de presupuestos participativos ya ha sido desarrollada reglamentariamente por algunos municipios (así ocurre con el Reglamento Municipal de Participación Ciudadana de Vélez-Málaga,

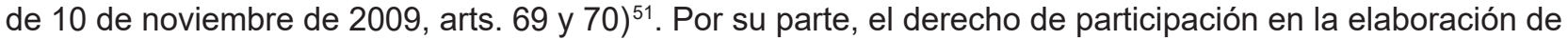
los anteproyectos de ordenanzas y reglamentos locales del art. 30 Ley 7/2017 también está contenido en el art. 133 LPAC $^{52}$. Además, se asimila a los trámites de audiencia al interesado y de información pública del procedimiento administrativo común. Como es conocido, estos ya estaban recogidos en la antigua Ley de 17 de julio de 1958, sobre Procedimiento Administrativo (arts. 91 y 130.5), en la derogada Ley 30/1992, de 26 de noviembre, de Régimen Jurídico de las Administraciones Públicas y del Procedimiento Administrativo Común (arts. 84 y 86) y en la vigente LPAC (arts. 82 y 83) ${ }^{53}$. El art. 49.b) LBRL también recoge los trámites de información pública y audiencia a los interesados en los procedimientos de elaboración de ordenanzas locales.

\section{d) La efectiva aplicación de la Ley}

En estas apreciaciones generales tienen que ponerse necesariamente de manifiesto algunas cuestiones que se suscitan en relación con la entrada en vigor y el desarrollo reglamentario. Destaca que la entrada en vigor de la Ley se ha producido a los doce meses de su publicación en el BOJA (disposición final tercera). Es decir, se ha retrasado hasta el 5 de enero de 2019 sin que hayan quedado claras las razones de tal demora. En este sentido, resulta interesante señalar que la disposición final tercera del "Proyecto de Ley de Participación Ciudadana de Andalucía" contemplaba un periodo de tiempo para su entrada en vigor aún mayor, de dieciocho meses ${ }^{54}$. Esta circunstancia unida a que la Ley concede un plazo de doce meses (desde su entrada en vigor) al Consejo de Gobierno de la Comunidad Autónoma para dictar las disposiciones necesarias para el desarrollo y ejecución de la ley (disposición final primera) y a los municipios andaluces para adaptar o, en su caso, aprobar sus RPC (disposición final segunda), posterga la existencia de una normativa en la materia hasta el 5 de enero de 2020, esto es un total de dos años ${ }^{55}$. De estos datos, no parece deducirse que el legislador autonómico tenga mucho interés en que la Ley despliegue efectos inmediatamente, lo que no deja de resultar curioso si se tiene en cuenta que la norma dice tener por objeto regular el derecho de participación de una manera «real y efectiva» así como el fomento de su ejercicio (art. 1.1).

49 GARCÍA DE ENTERRÍA, E. (1977: 308-313)

50 Como es sabido, el art. 133 LPAC se ha visto afectado por la STC 55/2018, de 24 de mayo de 2018. La Sentencia ha declarado la inaplicabilidad para las Comunidades Autónomas de gran parte del precepto por ser contrario al orden constitucional de competencias al descender a cuestiones procedimentales de detalle que desbordan el ámbito de lo básico, quedando únicamente a salvo su apartado 1 y el primer párrafo del apartado 4 (vid. FJ 7.c).

51 BOP de Málaga, núm. 243, de 22 de diciembre de 2009.

52 Sobre la participación de los vecinos en la elaboración de reglamentos municipales vid. PÉREZ LÓPEZ, E. (2018): "La participación pública en el ejercicio de la potestad reglamentaria municipal”, en LORA TAMAYO-VALLVÉ, M. (coord.): Retos y nuevas perspectivas de la participación pública. Valencia: Tirant lo Blanch, págs. 243-293.

53 En relación con la participación de las entidades representativas de intereses vid. REBOLLO PUIG, M. (1988): "La participación de las entidades representativas de intereses en el procedimiento de elaboración de disposiciones administrativas generales", en Revista de Administración Pública, núm. 125, págs. 99-166.

54 BOPA, núm. 342, de 14 de noviembre de 2016.

55 Sobre la disposición final primera y la disposición final segunda deben hacerse dos anotaciones. Así, la disposición adicional primera no aclara, como sí hace la segunda, desde cuándo tiene que contarse dicho plazo de doce meses. No obstante, entendemos que debe contabilizarse desde la publicación de la Ley 7/2017 en el BOJA. En relación con la disposición final segunda, hay que indicar que habla de «municipios» y no de entes locales, por tanto, de aquí no se desprende que los restantes entes locales tengan que proceder al desarrollo normativo en un determinado periodo de tiempo. 
REALA. Nueva Época - N.o 13, abril-septiembre 2020 - ISSN: 1989-8975 - DOI: 10.24965/reala.i13.10741 - [Págs. 47-74]

Consultas populares y entidades locales: a propósito de la Ley 7/2017, de 27 de diciembre, de Participación Ciudadana de Andalucía

En lo que respecta al desarrollo reglamentario a nivel autonómico, debe resaltarse que el 2 de agosto de 2018 fueron publicados en la sede electrónica de la Junta de Andalucía algunos «datos básicos» sobre el «Proyecto de Decreto ..../2018, por el que se regulan los Procesos de Participación Ciudadana en el ámbito de la Administración de la Junta de Andalucía» y se abrió un periodo de consulta pública para que la ciudadanía, organizaciones y asociaciones pudiesen expresar sus opiniones. Estos datos básicos consistían en una breve exposición de los siguientes aspectos: «antecedentes de la norma», "problemas que se pretenden solucionar», «necesidad y oportunidad de aprobación», «objetivos de la norma» y «posibles soluciones alternativas» ${ }^{56}$. Tras las elecciones autonómicas del 2 de diciembre de 2018, el nuevo Gobierno ha retomado la labor de desarrollo normativo y ha publicado en la sede electrónica de la Junta de Andalucía un texto articulado «Proyecto Decreto por el que se regulan los procesos de participación ciudadana en el ámbito de la Administración de la Junta de Andalucía» de fecha de 13 de junio de 2019 (en adelante nos referiremos al mismo como borrador del Proyecto de Decreto) cuyo contenido ha sido sometido a información pública a fecha de 15 de julio de 201957. El borrador del Proyecto de Decreto, fiel a su rúbrica, regula los procedimientos de participación ciudadana en el ámbito de la Administración de la Junta de Andalucía (arts. 1 y 3.1). Por lo tanto, quedan fuera de su regulación los procedimientos de participación ciudadana que tengan lugar en el ámbito local cuyos requisitos y aspectos procedimentales se regirán por lo que, con apoyo en la Ley $7 / 2017$ y en el resto de normativa aplicable, determine cada entidad local mediante reglamentos u ordenanzas (art. 17 Ley $7 / 2017$ ) ${ }^{58}$. Esta amplia remisión podría provocar que la pretendida potenciación de la participación ciudadana perseguida por la Ley quede en una mera declaración de intenciones si los entes locales no llevan a cabo un desarrollo normativo completo que posibilite que se lleven a la práctica estos mecanismos de participación ciudadana. Esto ocurriría si, por ejemplo, se limitasen a trasladar el contenido de la Ley $7 / 2017$. En particular, en lo que afecta a las consultas participativas existen distintos artículos que se remiten a su desarrollo reglamentario: el art. 36 (sobre el sistema de votación), el art. 48.5 y 6 (acerca del número de firmas necesario para que prospere la iniciativa ciudadana y del procedimiento para la recogida de firmas, plazos, presentación, identificación, recuento, validación y demás aspectos relativos a esta materia) y el art. 50 (sobre las limitaciones a la realización de las consultas participativas). Con posterioridad a la publicación de la Ley algunos municipios ya han aprobado o modificado sus RPC. La Ordenanza de gobierno abierto y participación ciudadana de Umbrete (Sevilla), de 22 de mayo de 2018, dice en su art. 3.e) ir en conformidad con la Ley 7/2017 pero no hace ninguna mención a las consultas participativas ${ }^{59}$. En cambio, el Reglamento Orgánico de Participación Ciudadana de Priego de Córdoba, de 7 de mayo de 2019, dedica su artículo 17 a este instrumento participativo, aunque lo cierto es que, con alguna salvedad (apartados 5 y 9 del art. 17), reproduce distintos artículos de la Ley $7 / 2017^{60}$. Por su parte, el RPC de Huelva se ciñe a recoger en el art. 34 el concepto de consulta participativa utilizado por la Ley $7 / 2017$ y en lo relativo al procedimiento para la recogida de firmas, plazos... se remite a un futuro acuerdo del Pleno en el art. 35; por tanto, en este caso nada nuevo añade ${ }^{61}$. En sentido parecido, la "Modificación y Adaptación del Reglamento de Participación Ciudadana de Alcalá la Real a la Ley 7/2017, de 27 de diciembre, de Participación Ciudadana de Andalucía" (municipio de Jaén), de 15 de octubre de 2019, destina a las consultas participativas los artículos 44 a 53, pero, igualmente, en este caso (a excepción de los arts. 52 y 53 in fine) se reitera lo dispuesto por la Ley $7 / 2017^{62}$. A la vista de lo anterior, quizá sería conveniente que la Junta de Andalucía elaborase un Reglamento «tipo» de Participación Ciudadana para facilitar el desarrollo normativo por los entes locales.

56 [20-07-2019]. Disponible en web: https://www.juntadeandalucia.es/servicios/participacion/normativa/consulta-previa/detaIle/152775.html.

57 La Resolución en la que el borrador del Proyecto de Decreto se somete a información pública está publicada en el BOJA, núm. 134, de 15 de julio de 2019. El borrador del Proyecto de Decreto [20-07-2019] está disponible en web: https://www.juntadeandalucia.es/export/drupaljda/normativa_en_elaboracion/19/07/0-\%20Borrador\%20para\%20trámite\%20de\%20Audiencia\%20e\%20Informes.pdf.

58 Como señala REBOLLO PUIG, M., lo habitual es que los reglamentos locales se aprueben con el nombre de ordenanzas. No obstante, se suele utilizar el de reglamentos para los que sean organizativos del ente local y sus servicios sin tener una relevancia directa para los ciudadanos en general, (2017c): "La potestad reglamentaria", en REBOLLO PUIG, M. y VERA JURADO, D. (dirs.): Derecho Administrativo. Madrid: Tecnos (Tomo I), págs. 223-266.

59 BOP de Sevilla, núm. 141, de 20 de junio de 2018.

60 BOP de Córdoba, núm. 97, de 23 de mayo de 2019.

61 BOP de Huelva, núm. 147, de 1 de agosto de 2019.

62 BOP de Jaén, núm. 202, de 22 de octubre de 2019. 
REALA. Nueva Época - N.o 13, abril-septiembre 2020 - ISSN: 1989-8975 - DOI: 10.24965/reala.i13.10741 - [Págs. 47-74]

Consultas populares y entidades locales: a propósito de la Ley 7/2017, de 27 de diciembre, de Participación Ciudadana de Andalucía Inmaculada Ruiz Magaña

\subsection{Los procedimientos de participación ciudadana mediante consultas populares}

\subsubsection{Instrumentos de consulta popular}

Las consultas populares se regulan en el Capítulo IV del Título III de la Ley $7 / 2017$, que queda integrado solo por los arts. 25 y 26 . Según el art. 25:

«Las Administraciones públicas andaluzas podrán recabar la opinión de la ciudadanía sobre determinados asuntos o políticas públicas de su competencia mediante los instrumentos de consultas populares a los que se refiere el artículo 78 del Estatuto de Autonomía para Andalucía, de conformidad con lo establecido en esta ley y en las disposiciones reglamentarias que la desarrollen, con la finalidad de valorar los efectos reales de sus actuaciones públicas u orientar decisiones sobre las mismas».

Como puede observarse este precepto no es muy innovador, pues se limita a hacer unas manifestaciones que ya están previstas en el art. 78 EAAnd 2007. Algo más de información aporta el art. 26 que habla de los diferentes «instrumentos de consulta popular» y facilita una breve definición de cada uno de ellos. Estos son:

- Encuestas: realizadas mediante técnicas demoscópicas.

- Audiencias públicas: mediante un procedimiento oral y público las Administraciones públicas posibilitan a los sujetos afectados por una política pública ser escuchados antes de adoptar una decisión.

- Foros de participación: son espacios de debate que tienen por objeto reflexionar sobre los efectos de una política pública y elaborar análisis valorativos de los efectos reales de dichas políticas en la ciudadanía.

- Paneles ciudadanos: son espacios de información que tienen como finalidad responder a las consultas planteadas sobre asuntos de interés público y, en especial, sobre las expectativas de futuro de los ciudadanos.

- Jurados ciudadanos: son grupos que tienen por objeto analizar los efectos de acciones, proyectos o programas llevados a cabo por la Administración.

- Consultas participativas: esta figura, a diferencia de las anteriores, se regula con bastante detenimiento. Muestra de esto es que el Capítulo VII, que es el que se dedica a las mismas, tenga una extensión de casi veinte artículos (arts. 33 al 50).

El art. 26, siguiendo el art. 78 EAAnd 2007, utiliza un concepto sumamente amplio de instrumentos de consulta popular que, de acuerdo con lo expuesto previamente, deben entenderse catalogados como consultas populares no celebradas por vía de referéndum. Recuérdese que a las tres primeras figuras -encuestas, audiencias públicas y foros de participación- hace expresa referencia el art. 78 EAAnd 2007 y que las restantes - paneles ciudadanos, jurados ciudadanos y consultas participativas- han sido creadas por la Ley 7/2017 en base a la cláusula numerus apertus «cualquier otro instrumento de consulta popular» que el artículo incluye ${ }^{63}$. De este modo, el precepto realiza una enumeración indiscriminada de las diferentes modalidades que pueden adoptar las consultas populares sin que se lleguen a establecer claras diferencias entre los procedimientos ni previsiones más concretas, con la salvedad de lo que a las consultas participativas se refiere. Por esta razón se centra a continuación la atención en el tratamiento normativo de estas últimas.

\subsubsection{Las consultas participativas sectoriales locales}

El Capítulo VII del Título III se estructura en tres secciones: la primera contiene unas disposiciones generales (arts. 33 al 43), la segunda se ocupa de las consultas participativas autonómicas (arts. 44 al 47 ) y la

63 La Ley 30/1992, de 26 de noviembre, de Régimen Jurídico de las Administraciones Públicas y del Procedimiento Administrativo Común ya regulaba los sondeos y encuestas de opinión (art. 78.2) así como las audiencias públicas (art. 84) como instrumentos de participación de los ciudadanos en el procedimiento administrativo (BUENO ARMIJO, 2008b: 218). Algunos RPC también reconocían con carácter previo a la Ley 7/2017 la posibilidad de utilizar las encuestas y sondeos para recabar la opinión de los vecinos en el ámbito inframunicipal. Es el caso del RPC de Granada, ya referenciado, cuyo art. 25 habla del ámbito «de un distrito, de un barrio, de varios». En igual sentido el RPC de Almería, de 4 de enero de 2013, art. 23 (BOP de Almería, núm. 20, de 30 de enero de 2013, modificado por el BOP, núm. 25, de 7 de febrero de 2017). 
REALA. Nueva Época - N.o 13, abril-septiembre 2020 - ISSN: 1989-8975 - DOI: 10.24965/reala.i13.10741 - [Págs. 47-74]

Consultas populares y entidades locales: a propósito de la Ley 7/2017, de 27 de diciembre, de Participación Ciudadana de Andalucía Inmaculada Ruiz Magaña

tercera de las consultas participativas locales (arts. 48 al 50). Por razones obvias se va a prestar atención al contenido de la sección primera y de la tercera, prescindiendo del de la segunda que excede del objeto de este trabajo al tratar las consultas participativas de ámbito autonómico.

\title{
A) Concepto
}

El art. 34.1 proporciona un concepto de lo que debe entenderse por consulta participativa. Según su literalidad:

\begin{abstract}
«(...) se entiende por consulta participativa, autonómica o local, el instrumento de participación ciudadana que tiene por objeto el conocimiento de la opinión de un determinado sector o colectivo de la población, mediante un sistema de votación de contenido no referendario, sobre asuntos de interés público que le afecten».
\end{abstract}

Así, se presenta como un instrumento de participación ciudadana cuyas características son: i) estar dirigido a conocer la opinión de un determinado sector o colectivo de la población, esto es, no de la totalidad sino de parte de ella (por esta razón en adelante nos referiremos a las mismas como consultas participativas sectoriales); ii) realizarse mediante un sistema de votación no referendatario; y iii) tratar sobre asuntos de interés público que afecten a ese colectivo (sobre los asuntos que pueden someterse a consulta se volverá más adelante). Para arrojar luz sobre esta descripción debe traerse a colación la doctrina del Tribunal Constitucional. Con carácter previo, se ha citado un extracto de la STC 31/2010 (FJ 69) que señalaba, entre otros rasgos de la consulta popular celebrada por vía de referéndum, que no recaba la opinión de cualquier colectivo sino que su objeto se refiere estrictamente al parecer del cuerpo electoral. Pues bien, con cita de esta Sentencia, la STC 31/2015, de 25 de febrero-que resuelve el recurso de inconstitucionalidad interpuesto en relación con diversos preceptos de la Ley del Parlamento de Cataluña 10/2014, de 26 de septiembre, de consultas populares no referendarias y otras formas de participación ciudadana- determina que:

«(...) En contraposición al referéndum, las consultas no referendarias recaban la opinión de cualquier colectivo (STC 31/2010, de 28 de junio, FJ 69), por lo que articulan "voluntades particulares o colectivas, pero no generales, esto es, no imputables al cuerpo electoral" (STC 103/2008, de 11 de septiembre, FJ 2).» (FJ 7).

$\mathrm{Y}$ admite su legalidad en los siguientes términos:

«(...) las consultas sectoriales (...) son cauces de participación cuya regulación por el legislador autonómico catalán resulta posible en consideración al título competencial establecido en el art. $122 \mathrm{EAC},(\ldots) »(\mathrm{FJ} 9)$.

Por tanto, las Comunidades Autónomas pueden regular las consultas sectoriales; si bien, esto no impide que el legislador estatal pueda establecer aspectos básicos de las consultas populares de ámbito local en virtud de la competencia estatal sobre las bases del régimen jurídico de las Administraciones públicas del art. 149.1.18. ${ }^{\circ} \mathrm{CE}$ (FJ 10). Es relevante hacer hincapié en que el colectivo destinatario de la consulta sectorial en ningún caso puede «configurarse de un modo tal que el resultado de la consulta pueda imputarse al conjunto de la ciudadanía o cuerpo electoral.» (FJ 9). De todo lo anterior parece colegirse que cuando se consulte a los ciudadanos de forma general estaremos ante un referéndum y cuando se consulte a los sujetos de un colectivo (que no coincida con el cuerpo electoral) estaremos ante consultas no referendatarias ${ }^{64}$. A juicio de FERNÁNDEZ RAMOS y ORDUÑA PRADA este modelo de consulta no referendataria tiene su origen en los recientes pronunciamientos de los tribunales sobre las competencias autonómicas relativos al referéndum y en la rigidez de los requisitos interpretativos del art. $71 \mathrm{LBRL}^{65}$. Recientemente, también otras Comunidades

64 Así lo ha señalado VELASCO CABALLERO, F. (2015): “¿Son aún posibles las consultas municipales?”, en Instituto de Derecho Local de la Universidad Autónoma de Madrid UAM. [21-06-2019] Disponible en web: http://www.idluam.org/blog/son-aun-posibleslas-consultas-municipales-francisco-velasco/.

65 Finalizada la redacción de este trabajo se ha publicado el artículo del Profesor FERNÁNDEZ RAMOS, S. (2019): "Las consultas populares no referendatarias mediante votación: ¿un artificio del derecho público español?", en Revista General de Derecho Administrativo, núm. 52, págs. 4-6, al que, por razones obvias, no he podido referirme con detenimiento. ORDUÑA PRADA, E. (2017: 87-89 y 92$)$. 
REALA. Nueva Época - N.o 13, abril-septiembre 2020 - ISSN: 1989-8975 - DOI: 10.24965/reala.i13.10741 - [Págs. 47-74]

Consultas populares y entidades locales: a propósito de la Ley 7/2017, de 27 de diciembre, de Participación Ciudadana de Andalucía

Autónomas como las Islas Baleares y Navarra han regulado modalidades de consulta popular de carácter no referendatario (por tanto, dirigidas a un sector de la población distinto del cuerpo electoral). En ambos casos la denominación que se ha asignado a esta figura es la de «consultas ciudadanas» y su regulación se contiene, respectivamente, en los arts. 50 a 88 de la Ley 12/2019, de 12 de marzo, de consultas populares y procesos participativos y en los arts. 25 a 28 de la Ley Foral 12/2019, de 22 de marzo, de participación democrática en Navarra ${ }^{66}$.

\section{B) La exclusión de las consultas populares de la Ley 2/2001}

De lo expuesto hasta ahora ya se desprende que las consultas participativas sectoriales de la Ley $7 / 2017$ no son las mismas que las consultas populares de la Ley 2/2001 (como se ha visto, estas últimas, entre otras cosas, desarrollan el art. 71 LBRL y requieren autorización del Gobierno de la Nación). De forma general, el art. 16.3 Ley 7/2017 anuncia que los procedimientos de participación ciudadana «complementan aquellos expresamente previstos en las normas generales y sectoriales, las cuales deberán aplicarse con el alcance y efectos establecidos en cada caso». Más específico es el art. 33.2 que hace mención expresa a las consultas populares de la Ley 2/2001 y las excluye tajantemente del ámbito de aplicación de la Ley 7/2017 del siguiente modo:

«Quedan excluidas de la presente ley las consultas reguladas por la Ley 2/2001, de 3 de mayo, de regulación de las consultas populares locales en Andalucía».

El legislador autonómico se muestra particularmente preocupado porque no se confundan las consultas participativas sectoriales de la Ley $7 / 2017$ con las consultas populares de la Ley $2 / 2001$. Prueba de ello es que en el Borrador del Proyecto de Decreto por el que se regulan los procesos de participación ciudadana en el ámbito de la Administración de la Junta de Andalucía, ya referenciado, se dedique nuevamente un artículo a insistir en la idea de que nada tienen que ver las consultas de la primera Ley con las de la segunda ${ }^{67}$.

A lo anterior hay que añadir que en la Ley $7 / 2017$ hay otra referencia indirecta a las consultas populares de la Ley 2/2001. Se trata del art. 34.3, que habla de una consulta: i) «de carácter general» (que, por tanto, afecta a la totalidad de la población), ii) que requiere que el municipio solicite la autorización del Gobierno de la Nación y, iii) se remite a la LBRL. Estos elementos, que se corresponden con la consulta popular del art. 71 LBRL y, por ende, de la Ley $2 / 2001$, son contrarios a los del art. 34.1 Ley $7 / 2017$. Es cierto que el apartado 3 del art. 34 está diciendo algo coherente, pero en nuestra opinión la ubicación que se ha dado a ese contenido no es la más acertada. No tiene mucho sentido que se haga esa declaración cuando el artículo anterior (art. 33.2) ha excluido de la Ley $7 / 2017$ las consultas populares reguladas por la Ley $2 / 2001$, y mucho menos que sea dentro del artículo que se ocupa de la "Definición" (así se rubrica el art. 34) de las consultas participativas sectoriales. Aunque resulta evidente que la interpretación conforme a la Constitución es entender que el art. 34 solo regula estas últimas y que su apartado 3 se refiere por razones sistemáticas, a modo aclarativo, a las consultas del art. 71 LBRL, lo anterior podría dar lugar a confusión y llevar a pensar que está definiendo otra modalidad de consulta participativa dirigida a la generalidad de la población ${ }^{68}$.

66 Vid. las reflexiones de FERNÁNDEZ RAMOS, S. (2019: 43-45) sobre el tratamiento normativo de las leyes andaluza, balear, catalana y navarra de las consultas populares no referendatarias y su viabilidad.

67 El art. 3.2 «Ámbito de aplicación» recalca que «Las consultas reguladas en el Capítulo VII de la Ley 7/2017, de 27 de diciembre (...) son instrumentos alejados del objeto, sujeto y procedimiento de las consultas populares referendatarias o sometidas al ámbito de aplicación de la Ley 2/2001, de 3 mayo, de regulación de las consultas populares locales en Andalucía».

68 En esta línea, en relación con el Anteproyecto de Ley de Participación Ciudadana de Andalucía, PÉREZ ALBERDI, M. R. señalaba que «la consulta dirigida al conjunto de la población de la colectividad territorial mediante el voto nos sitúa en el terreno del referéndum y, en consecuencia, fuera del ámbito de competencias de la Comunidad Autónoma andaluza» (2014): "Democracia participativa en Andalucía. A propósito del Anteproyecto de Ley de participación ciudadana”, en Cuadernos Manuel Giménez Abad, núm. 8 , pág. 171, vid. asimismo pág. 170. Por su parte, el Documento de propuestas para el Anteproyecto de Ley Andaluza de Participación Ciudadana de 31 de mayo de 2013 no concebía las consultas participativas locales como sectoriales: las presentaba como «consultas populares no referendarias de ámbito local (...) más flexibles al no precisar realizar todo el trámite administrativo para la autorización del Estado y así mismo no obliga a utilizar el censo electoral, permite utilizar el padrón municipal; con ello, además, se posibilita que podrán participar las personas empadronadas mayores de 16 años». Vid. pág. 15 del Documento de propuestas para el Anteproyecto de Ley Andaluza de participación ciudadana de 31 de mayo de 2013. [16-07-2019] Disponible en web: https://docplayer.es/15522570Documento-de-propuestas-para-el-anteproyecto-de-ley-andaluza-de-participacion-ciudadana.html. Estos elementos sirvieron de base a IBÁÑEZ MACÍAS, A. (2013: 104) para concluir que las consultas que se proponían eran «verdaderos referendos». 
REALA. Nueva Época - N.o 13, abril-septiembre 2020 - ISSN: 1989-8975 - DOI: 10.24965/reala.i13.10741 - [Págs. 47-74]

Consultas populares y entidades locales: a propósito de la Ley 7/2017, de 27 de diciembre, de Participación Ciudadana de Andalucía Inmaculada Ruiz Magaña

\section{C) Derecho a participar}

El art. 35 se dedica a los sujetos que tienen derecho a participar, según su tenor:

«Con carácter general, tendrán derecho a participar en las consultas participativas autonómicas o locales, reguladas en el presente capítulo, todas las personas mayores de 16 años pertenecientes al sector o colectivo de la población que tenga interés directo en el tema objeto de consulta, y que reúnan los requisitos establecidos en el artículo 6.1. Este límite de edad podrá ser obviado en asuntos que afecten directamente a la infancia y los derechos que ostentan».

De este modo, el derecho alcanza a los mayores de dieciséis años que reúnan las condiciones del art. 6.1 y que pertenezcan al sector o colectivo de la población que tenga «interés directo» en el tema objeto de la consulta. Los arts. 36 y 43.1 Ley 7/2017 también aluden al «interés directo» pero nada aclaran sobre su concepto. Es sabido que estos términos ya se utilizaban tanto en la Ley, de 27 de diciembre de 1956, reguladora de la Jurisdicción Contencioso-Administrativa como en la Ley, de 17 de julio de 1958, de Procedimiento Administrativo, si bien, no parece que el legislador autonómico esté pensando en la noción que se establecía en la legislación preconstitucional y que el Tribunal Constitucional ha reconducido al de «interés legítimo» del art. 24 CE. Para saber quiénes pueden ejercer el derecho es necesario acudir al art. 6.1 Ley 7/2017. Este reconoce el derecho de participación, por una parte, a los ciudadanos con capacidad de obrar de acuerdo con la normativa básica de procedimiento administrativo común que tengan la «condición política de andaluces». De acuerdo con el art. 5.1 EAAnd 2007 tienen dicha condición aquellos ciudadanos españoles que tengan vecindad administrativa en cualquier municipio de Andalucía (es conocido que según el art. 15 LBRL el carácter de vecino se adquiere en el momento de inscripción en el padrón). Por otra parte, también reconoce el derecho a las personas extranjeras residentes en Andalucía. Así, la Ley 7/2017 cumple con el propósito que marcan los arts. 5.3 y 30.2 EAAnd 2007 de promover la participación de los ciudadanos extranjeros residentes en Andalucía ${ }^{69}$.

\section{D) Asuntos objeto de consulta}

El art. 34.2 Ley 7/2017 dispone que las consultas participativas sectoriales tienen por objeto «(...) cuestiones relativas a materias de la competencia de las entidades locales andaluzas», añadiendo una frase de difícil comprensión: «En estas se atenderá a lo establecido en el capítulo IV, título V, relativo a "Información y participación ciudadanas", contenido en la Ley 7/1985, de 2 de abril, reguladora de las Bases de Régimen Local». Esta remisión no se entiende muy bien, pues este capítulo (compuesto por los artículos 69 a 72) tiene un contenido de lo más heterogéneo -sirva de ejemplo que, entre otras cuestiones, se abordan temas como la publicidad de las sesiones del Pleno de las corporaciones locales, la iniciativa legislativa popular o los deberes de las Administraciones públicas con competencias de ordenación territorial y urbanística- y el art. 34.2 Ley 7/2017 en lugar de aclarar a qué se refiere genera mayor confusión.

Por su parte, el art. 37 señala que:

«Las consultas reguladas en este capítulo podrán plantearse exclusivamente sobre aquellos asuntos de interés público de la respectiva competencia de la Administración pública convocante, sobre cuestiones que estén motivadas por el ejercicio de dicha competencia y que tengan relevancia para la vida ordinaria de un determinado sector o colectivo de la población».

En la interpretación del alcance de estos requisitos resulta imprescindible la delimitación negativa que hace el art. 38. Según este precepto están excluidos aquellos asuntos que sean contrarios al ordenamiento jurídico, que no sean competencia de las entidades locales andaluzas, que cuestionen la dignidad de la persona o sus derechos fundamentales, que se refieran a las Haciendas locales o traten de asuntos

69 Al estar fuera del art. 6.1, debe entenderse que no tienen derecho a participar en las consultas participativas sectoriales los sujetos a los que hacen referencia los arts. 6.3 y 7 . El art. 6.3 reconoce el ejercicio del derecho de participación a las «entidades de participación ciudadana» y contiene una enumeración de los requisitos que deben cumplir para que a los efectos de la Ley tengan tal consideración. El art. 7 hace una mención a los ciudadanos andaluces en el exterior pero, a diferencia del art. 6 , no se trata de un reconocimiento explícito del derecho de participación sino que se limita a encomendar a la Administración de la Junta de Andalucía adoptar las «medidas necesarias para fomentar y facilitar la participación efectiva» de estos. Sobre el concepto de ciudadanos andaluces en el exterior cfr. art. 2.1 de la Ley 8/2006, de 24 de octubre, del Estatuto de los Andaluces en el mundo. 
REALA. Nueva Época - N.o 13, abril-septiembre 2020 - ISSN: 1989-8975 - DOI: 10.24965/reala.i13.10741 - [Págs. 47-74]

Consultas populares y entidades locales: a propósito de la Ley 7/2017, de 27 de diciembre, de Participación Ciudadana de Andalucía

públicos que constituyan el ejercicio del derecho fundamental reconocido por la Constitución en el art. $23^{70}$. Una lectura detenida de los arts. 37 y 38 permite advertir la amplitud con la que están redactados, lo que en la práctica puede facilitar que numerosos asuntos puedan ser rechazados por verse afectados por el art. 23 CE.

\section{E) Ámbito territorial y convocatoria}

Las consultas participativas pueden ser convocadas por las diputaciones provinciales o por los ayuntamientos, previo acuerdo por mayoría absoluta del Pleno de la entidad local (arts. 40.2 y 3 y 49.1$)^{71}$. La competencia para la convocatoria de la consulta varía atendiendo al ámbito territorial en el que vaya a tener lugar. Así, corresponde al presidente de la diputación provincial cuando el ámbito territorial sea: a) la provincia o, b) el «ámbito territorial superior al municipal e inferior al provincial» (art. 40.2). Por consiguiente, en este último caso, podría entrar el ámbito territorial de una mancomunidad de municipios aunque la Ley no lo mencione expresamente. $Y$, atañe al alcalde del municipio cuando el ámbito territorial sea: a) el término municipal o, b) el:

«ámbito territorial inferior al municipio, bien de distrito, cuando se trate de municipios de gran población, bien en el ámbito de una entidad de gestión descentralizada o de un ente desconcentrado, conforme a lo que se establece en la Ley $7 / 1985$, de 2 de abril, reguladora de las Bases del Régimen Local» (art. 40.3).

En relación a esto último debe hacerse constar lo siguiente:

- Cuando alude al ámbito de una «entidad de gestión descentralizada» hay que entender que se refiere a las antiguas entidades de ámbito territorial inferior al municipio, que han sido suprimidas por la LRSAL. No obstante, de conformidad con las disposiciones transitorias cuarta y quinta LRSAL estas aún existen y mantienen su condición de entidad local y, por ende, su personalidad jurídica. En Andalucía, según la LAULA, estas entidades son las entidades vecinales y las entidades locales autónomas (arts. 109.2.b y 113) (2. $^{72}$

- El art. 40.3 también hace referencia al ámbito de un «ente desconcentrado». Como es sabido, las entidades de ámbito territorial inferior al municipio han sido sustituidas por «entes de ámbito territorial inferior al municipio» (art. 24 bis LBRL), que son en realidad órganos desconcentrados. Como indica PIZARRO NEVADO, «el término "ente" sugiere una existencia autónoma del municipio de la que no disfrutan los órganos desconcentrados», que carecen de personalidad jurídica y del carácter de entidad local ${ }^{73}$. En base a lo anterior, debe señalarse que el legislador autonómico debería haber utilizado en el art. 40.3 otra terminología ya que la expresión «ente desconcentrado» genera confusión. Aún así, se infiere que han de entenderse incluidos en el ámbito territorial, por una parte, los mal llamados por el art. 24 bis LBRL «entes de ámbito territorial inferior al municipio» que como se ha dicho son órganos desconcentrados. Y, por otra parte, los órganos territoriales de gestión desconcentrada del art. 24.1 LBRL cuya creación es facultativa para los municipios de régimen común pero obligada para los municipios de gran población (arts. 24.2 y $128.1 \mathrm{LBRL}$ ). Según el art. 109.2.a) LAULA estos órganos desconcentrados pueden ser denominados distritos, (no era

70 Aunque siempre es conveniente tener presentes ciertas ideas, algunas de las puntualizaciones son repetitivas e innecesarias. Es el caso de la prohibición de que el asunto sea contrario al ordenamiento jurídico o la prohibición de que no sea competencia de las entidades locales, que ya se contienen en los arts. 11.2, 13 y 43.2 y arts. 6.1, 11.2, 34.2 y 37 Ley $7 / 2017$, respectivamente.

71 Como se ha señalado anteriormente, el art. 78 EAAnd 2007 atribuye a la Junta de Andalucía competencias sobre un amplio catálogo de actuaciones entre las que se encuentra la de la convocatoria "por ella misma o por los entes locales» de las consultas populares. Con la elaboración de la Ley 7/2017 el legislador ha hecho uso de esta opción que ofrece el EAAnd 2007 de confiar a los entes locales la convocatoria y ha extendido la competencia a las diputaciones provinciales, pues hasta el momento en el ámbito local solo podían ser convocadas por los alcaldes de los ayuntamientos ex. art. 71 LBRL, art. 41.26 ROF y art. 11.1 Ley 2/2001.

72 En relación con las entidades locales autónomas en un futuro habrá que estar al texto normativo que resulte del "Proyecto de Decreto por el que se regulan las entidades locales autónomas de Andalucía". [16-07-2019] Su primer borrador, de fecha de 4 de julio de 2018, está disponible en web: https://www.juntadeandalucia.es/export/drupaljda/normativa_en_elaboracion/18/07/05\%20Borrador\%20 Decreto\%2010\%204-7-18.pdf.

73 PIZARRO NEVADO, R. (2017: 66, asimismo vid. 66-69). Sobre los conceptos de descentralización y desconcentración vid. CARBONELL PORRAS, E. (2017): “La organización administrativa. Conceptos, principios y reglas generales”, en REBOLLO PUIG, M. y VERA JURADO, D. (dirs.): Derecho Administrativo. Madrid: Tecnos (Tomo I), págs. 295-298. 
por tanto necesaria la referencia expresa del art. 40.3 Ley 7/2017 a los distritos de los municipios de gran población, que ya se dan por incluidos como órganos desconcentrados que son), barrios, aldeas, pedanías...

En ambos casos la convocatoria adopta la forma de decreto, que debe realizarse en el plazo de cuarenta y cinco días desde que haya sido acordada por el pleno de la entidad local. Este tiene que publicarse en el BOP correspondiente con un mínimo de treinta días de antelación a la fecha de celebración, así como en el tablón de anuncios de la corporación local convocante y, en su caso, en la sede electrónica, portal o página web, en el plazo de cinco días contados a partir de la publicación en el boletín correspondiente.

Junto a lo anterior deben tenerse en consideración las restricciones temporales contenidas en los arts. 15 y 41 . Según estos preceptos las consultas no pueden ser convocadas ni desarrollarse en los periodos que median entre la convocatoria de elecciones a Cortes Generales y la constitución de las nuevas Cámaras; entre la convocatoria de las elecciones al Parlamento de Andalucía y los noventa días posteriores a la toma de posesión del nuevo Presidente; entre la convocatoria y la celebración de un referéndum de los previstos en la normativa vigente cuando este afecte al ámbito territorial de la consulta participativa; y entre la convocatoria de las elecciones municipales y los noventa días posteriores a la toma de posesión del nuevo gobierno municipal. Se trata de limitaciones que van más allá de las establecidas por el art. 4 de la Ley 2/2001 para las consultas populares locales y que nuevamente muestran aspectos de la Ley $7 / 2017$ a los que es difícil encontrar una explicación. Por ejemplo, no se alcanza a comprender qué razones justifican que tengan que transcurrir noventa días desde la toma de posesión del gobierno municipal para que se pueda convocar o celebrar una consulta.

\section{F) Iniciativa}

Corresponde a las administraciones públicas la iniciación del procedimiento para la convocatoria de las consultas participativas sectoriales. Pueden hacerlo, bien de oficio bien por iniciativa ciudadana del sector o colectivo de la población que tenga interés directo en el tema objeto de consulta (arts. 14 y 43). En ambos casos la iniciativa debe ser objeto de informe de los órganos competentes por razón de la materia y de dictamen del Consejo Consultivo de Andalucía.

a) La iniciativa institucional compete a la corporación local y se realiza a través de acuerdo adoptado por mayoría simple (se sigue, por tanto, la regla general de que los acuerdos se obtienen mediante mayoría simple en virtud de los arts. 47.1 y 123.2 LBRL) a propuesta del presidente de la entidad local, de al menos dos partidos con representación en los plenos municipales o provinciales o de al menos un tercio de los miembros de la respectiva corporación (art. 48.1 Ley 7/2017). De esta forma, a diferencia del art. 6.1 Ley 2/2001 que contempla únicamente la iniciación mediante acuerdo adoptado por mayoría simple de un grupo municipal, la Ley $7 / 2017$ tiene en cuenta las diferencias organizativas locales pues no todos los Ayuntamientos se organizan en grupos municipales.

b) Más dudas surgen en relación con la iniciativa ciudadana, en particular sobre el art. 48.2 y $3^{74}$. Resulta contradictorio que según el apartado 2 del art. 48 la «convocatoria de una consulta participativa local deberá ser promovida por personas físicas o jurídicas (...) mediante el número mínimo de firmas a que se refiere este artículo» y que, seguidamente, en el apartado 3 se requiera que el número de firmas sea de «aquellos que tuvieran derecho a participar (...) conforme al artículo 35». Pues, ya se ha visto que el art. 35 solo menciona a las personas físicas del art. 6.1, lo que nos llevaba a entender que la intención del legislador era excluir la participación de las personas jurídicas o entidades de participación ciudadana en los procedimientos de consultas participativas.

Los apartados 3, 4 y 5 del art. 48 establecen los criterios que determinan el número de firmas necesario para solicitar la convocatoria de la consulta, si bien presentan algunos puntos que no son de fácil comprensión -esto resulta llamativo si se tiene en cuenta que esta Ley lleva en tramitación parlamentaria desde $2014-{ }^{75}$. Por ejemplo, puede resaltarse que el art. 48.5 habla de la consulta que se celebre en

74 Esta iniciativa debe entenderse rechazada por silencio negativo si transcurren tres meses desde la presentación de la petición sin que la Administración correspondiente haya acordado el inicio (art. 14 párrafo $2 .^{\circ}$ ).

75 La primera versión del Anteproyecto aprobada por el Consejo de Gobierno es de fecha de 1 de agosto de 2014. [16-07-2019] Está disponible en web: https://www.juntadeandalucia.es/export/drupaljda/normativa_en_elaboracion/16/07/Anteproyecto\%20Ley\%20 
REALA. Nueva Época - N.o 13, abril-septiembre 2020 - ISSN: 1989-8975 - DOI: 10.24965/reala.i13.10741 - [Págs. 47-74]

Consultas populares y entidades locales: a propósito de la Ley 7/2017, de 27 de diciembre, de Participación Ciudadana de Andalucía

un «ámbito territorial acotado» pero no explica qué debe entenderse por tal, ya que estos términos no se han utilizado previamente por la Ley. Por otra parte, sorprende que el art. 48.3 se sirva de unos tramos de población y unos porcentajes que son similares a los empleados por el art. 6.1 Ley 2/2001. Esto carece de justificación si se atiende a que esta última Ley diseña un procedimiento para una consulta dirigida a los vecinos del municipio que tienen derecho de sufragio activo en las elecciones municipales mientras que las consultas participativas de la Ley $7 / 2017$ van dirigidas a un concreto colectivo mucho más restringido.

\section{G) Efectos}

Con carácter general la Ley prevé que los procedimientos de participación ciudadana «no alterarán ni supondrán menoscabo de las potestades y competencias del correspondiente ámbito de gobierno, autonómico o local, en la adopción de las decisiones que les corresponden» (art. 16.1). De aquí ya se puede inferir que no cabe que los resultados de dichos procedimientos tengan carácter vinculante. Si bien, como ya se ha señalado, la idea de que las formas de participación no pueden menoscabar las facultades de decisión de los órganos representativos no es nueva sino que está recogida en el art. 69.2 LBRL. En esta línea, el art. 39.1 aclara expresamente que las consultas participativas son de «naturaleza consultiva y no vinculante» (art. 39.1). No obstante, el órgano competente del gobierno local -con independencia de que se aparte o asuma el resultado del procedimiento- tiene que justificar en el plazo máximo de treinta días las razones que le han llevado a tomar dicha decisión. A esta motivación debe darse publicidad en la sede electrónica, portal o página web del órgano que ostenta la iniciativa para la convocatoria, así como en los boletines oficiales si se considera oportuno. Ciertamente esta obligación de motivación es una medida positiva, pues como apunta PÉREZ ALBERDI «con ello, se refuerzan los instrumentos de control y evaluación del proceso participativo por parte de los ciudadanos» ${ }^{76}$.

Además de lo anterior, la realización de las consultas participativas sectoriales presenta restricciones cuantitativas (art. 50). El número de consultas que pueden llevarse a cabo anualmente debe concretarse reglamentariamente en función del asunto y colectivo al que vaya dirigida la consulta. Si bien, una vez publicado el decreto de la convocatoria, no se podrán promover consultas sobre el mismo objeto hasta transcurridos dos años a contar desde la celebración de la consulta o la inadmisión de la iniciativa.

Este apartado, denominado «efectos», quedaría incompleto sino se hiciese alusión al art. 16.4, que determina que.

«El cumplimiento de esta Ley será directamente exigible para hacer efectivos los derechos en ella reconocidos, aunque su omisión o infracción no afectará, en ningún caso, a la validez y eficacia del acto o decisión en cuyo procedimiento se prevea».

Será difícil que se consiga la efectividad a la que se apela cuando, por una parte, se niega que el incumplimiento de las previsiones legales afecte al acto o decisión vinculado con el resultado del procedimiento y, por otra, no se regula ningún régimen de garantías sobre la exigibilidad de los derechos ni se prevén consecuencias o sanciones para el respectivo órgano que haya incumplido -salvo las generales que resulten de aplicación según la legislación del empleado público, que no siempre resulta sencillo aplicar ante la indeterminación normativa-. En todo caso, sí parece claro que se cuestiona la efectividad del derecho a la participación que consagra el art. 1.1 Ley 7/2017 que afirma regularlo «de manera real y efectiva».

\section{UNA REFLEXIÓN FINAL}

La Ley 7/2017 merece una valoración positiva en cuanto que dota a la Comunidad Autónoma de Andalucía de una Ley en materia de participación ciudadana, que hasta el momento era inexistente, y amplía considerablemente el régimen jurídico de las consultas populares locales, en particular, a través de la regulación que hace de las consultas participativas sectoriales. Destaca que estas pueden operar en los ámbitos supramunicipal, municipal e inframunicipal, se completa así lo establecido por la Ley 2/2001 que

de\%20Participación\%20Ciudadana\%20(10\%20borrador\%20aprobado\%20en\%20Consejo\%20de\%20Gobierno).pdf Los sucesivos borradores están disponibles en web: https://www.juntadeandalucia.es/servicios/normas-elaboracion/detalle/96081.html.

76 PÉREZ ALBERDI, M. R. (2014: 170). 
REALA. Nueva Época - N. 13, abril-septiembre 2020 - ISSN: 1989-8975 - DOI: 10.24965/reala.i13.10741 - [Págs. 47-74]

Consultas populares y entidades locales: a propósito de la Ley 7/2017, de 27 de diciembre, de Participación Ciudadana de Andalucía

se limita solo a regular las consultas populares municipales. Al tener conocimiento de la existencia de dos leyes que se ocupan de las consultas populares se plantea la cuestión de cuál es la diferencia entre las que regula cada una de ellas. A este respecto, el legislador autonómico se ha limitado a mostrar un especial interés por dejar claro que en la Ley $7 / 2017$ no se están regulando las mismas consultas populares de la Ley 2/2001 (así lo evidencian los arts. 33.2 y 34.3 Ley 7/2017 y el art. 3.1 del Borrador del Proyecto de Decreto que desarrolla la Ley $7 / 2017$, ya referenciado). No obstante, de una lectura detenida de ambas leyes y sobre la base de la doctrina constitucional, puede deducirse que la principal diferencia estriba en que las consultas de la Ley 2/2001, que son desarrollo del art. 71 LBRL, son consultas populares referendatarias (en esencia, van dirigidas a la generalidad de la población, esto es, al cuerpo electoral y requieren para su celebración previa autorización del Gobierno de la Nación). En cambio, las consultas participativas sectoriales de la Ley 7/2017 son no referendatarias (destaca que están dirigidas a un sector o colectivo concreto de la población, que no puede coincidir en ningún caso con el cuerpo electoral, y se rigen por un procedimiento mucho más laxo que las anteriores). Este modelo de consulta popular no referendataria ha sido también acogido recientemente por la regulación de la Comunidad Autónoma de las Islas Baleares y la Comunidad Foral de Navarra, en la Ley 12/2019, de 12 de marzo y en la Ley Foral 12/2019, de 22 de marzo, respectivamente.

Sentado lo anterior y centrando la atención en el contenido de la Ley $7 / 2017$, debe ponerse de manifiesto que se trata de una regulación que presenta aspectos que no siempre son de fácil comprensión. En ocasiones la técnica jurídica empleada no es del todo clara y puede inducir a confusión. Así lo refleja el art. 40.3 que, al abordar el ámbito territorial en que puede tener lugar la consulta, habla de un «ente desconcentrado» cuando, como sabemos, la desconcentración no implica personalidad jurídica ni el carácter de entidad local. Otra muestra de lo anterior es que una vez que el art. 33.2 Ley 7/2017 excluye las consultas populares de la Ley 2/2001 del ámbito de la norma, seguidamente, el art. 34 (rubricado "Definición" de las consultas participativas) dedica el apartado 3 a las consultas populares del art. 71 LBRL, que son, las de la Ley 2/2001. Esto último podría llevar a pensar que el art. 34 Ley $7 / 2017$ se está refiriendo a una consulta participativa dirigida a la generalidad de la población. En la línea de lo expuesto, la Ley también presenta alguna contradicción. Sirva de ejemplo que según el apartado 2 del art. 48 la convocatoria de la consulta participativa debe ser promovida «por personas físicas o jurídicas» mediante un determinado número de firmas y que, a continuación, el apartado 3 del mismo precepto exige que el número de firmas sea de aquellos que tengan derecho a participar conforme al art. 35 , esto son, personas físicas.

Igualmente, procede poner de relieve algunas previsiones que resultan cuanto menos llamativas (esto se acentúa si se tiene en cuenta el largo periodo que la Ley que ha estado en tramitación parlamentaria) y podrían poner en cuestión la efectividad de la propia norma y, por tanto, su finalidad. Ejemplo de ello es que la Ley (art. 48.3) al regular la iniciativa ciudadana para solicitar la convocatoria de una consulta sectorial requiere un número de firmas necesario que es igual al que prevé la Ley 2/2001 (art. 6.1) para las consultas populares municipales a las que están llamadas a participar no un sector de la población sino todo el cuerpo electoral. Del mismo modo, quizás la ambigüedad con la que está redactado el art. 37 -que se refiere a los asuntos objeto de consulta- y la amplitud de los límites materiales del art. 38 pueda provocar que en la práctica numerosos asuntos sean rechazados. También es curioso que el legislador diga tener por objeto regular el derecho de participación ciudadana «de manera real y efectiva (...) así como el fomento de su ejercicio» (art. 1.1) pero la entrada en vigor no se haya producido hasta transcurrido un año de su publicación en el BOJA y se haya concedido otro año a la Comunidad Autónoma y a los municipios para adaptarse a la nueva normativa. Como se ha visto, nada dice la Ley de los restantes entes locales, por lo que, en consecuencia, hay que entender que estos no tienen plazo límite. De este modo, en los primeros, se retrasa la existencia de una normativa en la materia hasta el 5 de enero de 2020. De aquí no parece deducirse que el legislador autonómico tenga mucho interés en que la Ley despliegue efectos con inmediatez. Otro de los aspectos que puede tornarse en un inconveniente de cara a la efectividad de la Ley es la amplia remisión a la potestad normativa local, que es muy respetuosa con la autonomía local, pero, a su vez, puede dificultar la aplicación de la Ley (cfr. arts. 17, 36, 48.5 y 6 y 50). Es lo que podría ocurrir si los entes locales, al crear o adaptar sus RPC a la Ley $7 / 2017$, en lugar de completar lo establecido por la Ley se limitasen a reproducir su contenido. Es lo que ha sucedido con los RPC de Umbrete y de Priego de Córdoba y, en parte, con los RPC de Huelva y Alcalá la Real (ya referenciados). No obstante, quizás la elaboración del Decreto de desarrollo de la Ley 7/2017 sea una buena oportunidad para que el legislador subsane algunas de las deficiencias señaladas. Incluso la Junta de Andalucía podría elaborar un Reglamento «tipo» de Participación que facilite el desarrollo normativo por los municipios y demás entes locales. 


\section{ANEXO. «CONSULTAS POPULARES CELEBRADAS EN ANDALUCÍA»}

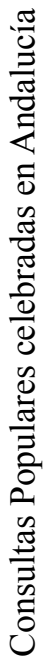
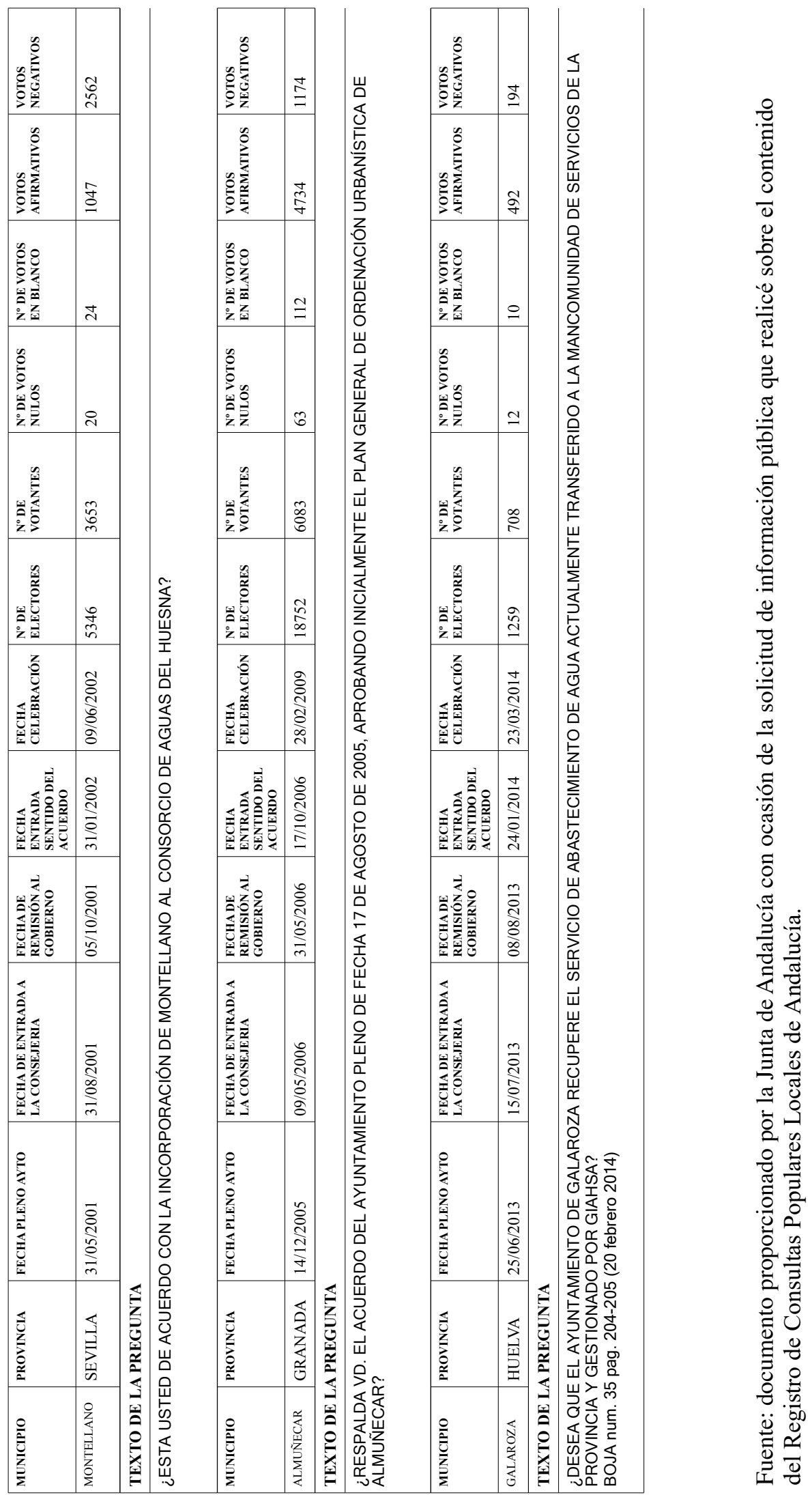


\section{REFERENCIAS BIBLIOGRÁFICAS}

ÁLVAREZ MONTOTO, J. (2009): "Las consultas populares en el ámbito local”, en Consultor de los Ayuntamientos y de los Juzgados, núm. 2, págs. 188-202.

BARATA I MIR, J. (1999): Los actos de gobierno en el ámbito municipal. Madrid: Tecnos.

BUENO ARMIJO, A. (2008a): "Competencias sobre consultas populares. En especial por vía de referéndum (Comentario al art. 78)", en MUÑOZ MACHADO, S. y REBOLLO PUIG, M. (dirs.): Comentarios al Estatuto de Autonomía para Andalucía, págs. 777-789. Pamplona: Civitas.

BUENO ARMIJO, A. (2008b): "«Consultas populares» y «referéndum consultivo»: una propuesta de delimitación conceptual y de distribución competencial”, en Revista de Administración Pública, núm. 177, págs. 195-228.

CANO CAMPOS, T. (2007): “Artículo 18”, en REBOLLO PUIG, M. (dir.): Comentarios a la Ley Reguladora de las Bases del Régimen Local, págs. 355-381. Valencia: Tirant lo Blanch (Tomo I).

CARBONELL PORRAS, E. (2005): “Concejo Abierto”, en MUCHOZ MACHADO, S. (dir.): Diccionario de Derecho Administrativo, págs. 546-556. Madrid: lustel (Tomo I).

CARBONELL PORRAS, E. (2013): “La planta local: análisis general y perspectivas de reforma”, en DÍEZ SÁNCHEZ, J. J. (coord.): La planta del gobierno local, págs. 17-60. Barcelona: Fundación Democracia y Gobierno Local.

CARBONELL PORRAS, E. (2014): "Sobre la reforma local y las competencias municipales propias", en Revista Vasca de Administración Pública, núm. especial 99-100, págs. 765-781.

CARBONELL PORRAS, E. (2017): “La organización administrativa. Conceptos, principios y reglas generales", en REBOLLO PUIG, M. y VERA JURADO, D. (dirs.): Derecho Administrativo, págs. 267-309. Madrid: Tecnos (Tomo I).

CARRASCO DURÁN, M. (2012): “Artículo 78. Consultas populares", en CRUZ VILLALÓN, P. y MEDINA GUERRERO, M. (dirs.): Comentarios Estatuto de Autonomía para Andalucía, págs. 1.278-1.296. Sevilla: Parlamento de Andalucía (Tomo II).

COSCULlUELA MONTANER, L. (1987): "El Concejo Abierto”, en Revista de Estudios de la Administración Local y Autonómica, núm. 234, págs. 199-294. DOI: https://doi.org/10.24965/reala.vi234.8500.

COSCULLUELA MONTANER, L. (1979): "La determinación constitucional de las competencias de las Comunidades Autónomas", en Revista de Administración Pública, núm. 89, págs. 7-60.

DE LA TORRE MARTÍNEZ, L. (2015): "La legitimación activa del «interés difuso»: ¿una nueva categoría para proteger la igualdad?", en Revista General de Derecho Administrativo, núm. 40, págs. 1-40.

FERNÁNDEZ RAMOS, S. (2005): La información y participación ciudadana en la Administración Local. Barcelona: Bosch.

FERNÁNDEZ RAMOS, S. (2007): “Artículo 71", en REBOLLO PUIG, M. (dir.): Comentarios a la Ley Reguladora de las Bases del Régimen Local, págs. 1.799-1.842. Valencia: Tirant Lo Blanch (Tomo II).

FERNÁNDEZ RAMOS, S. (2019): "Las consultas populares no referendatarias mediante votación: ¿un artificio del derecho público español?", en Revista General de Derecho Administrativo, núm. 52, págs. 1-46.

FERNÁNDEZ RAMOS, S. y PÉREZ MONGUIÓ, J. M. (2019): Vox populi: consultas populares y procesos participativos. Pamplona: Thomson Reuters Aranzadi.

FONT I LLOVET, T. (1985): “El referéndum local en España”, en Revista Catalana de Dret Públic, núm. 2-3, págs. 123130.

GARCÍA DE ENTERRÍA, E. (1977): "La participación del administrado en las funciones administrativas”, en AA.VV: Homenaje a Segismundo Royo-Villanova, págs. 305-318. Madrid: Moneda y Crédito.

GARCÍA GARCÍA, M. J. (2009): "La celebración de consultas populares a petición de los vecinos", en Revista Vasca de Administración Pública, núm. 83, págs. 45-90.

GÓMEZ FERNÁNDEZ, V. M. (2012): “Art. 78. Consultas populares”, en ORTíZ SÁNCHEZ, M. y CARRASCO LÓPEZ, I. (coords.): Comentarios al Estatuto de Autonomía para Andalucía, págs. 541-543. Sevilla: Instituto Andaluz de Administración Pública.

IBÁÑEZ MACÍAS, A. (2013): "Los referendos regional y local en el Estado autonómico. Sus bases y límites constitucionales", en Revista Vasca de Administración Pública, págs. 97-138.

JIMÉNEZ-BLANCO Y CARRILLO DE ALBORNOZ, A. (1987): “Artículo 15.2", en MUÑOZ MACHADO, S. (dir.): Comentarios al Estatuto de Autonomía de la Comunidad Autónoma de Andalucía, págs. 419-426. Madrid: Ministerio para las Administraciones Públicas e Instituto de Estudios de la Administración Local.

MARTÍN NÚÑEZ, E. (2012): "El referéndum y las consultas populares en las comunidades autónomas y municipios", en Revista Vasca de Administración Pública, núm. 94, págs. 95-131.

MARTÍNEZ ALONSO-CAMPS, J. L. (2010): "Las consultas populares municipales: consideraciones sobre el marco normativo y su identificación como referéndum”, en Anuario del Gobierno Local, núm. 1, págs. 447-486.

MUÑOZ MACHADO, S. (1977): "Las concepciones del Derecho Administrativo y la idea de participación en la Administración", en Revista de Administración Pública, núm. 84, págs. 519-535.

NARANJO DE LA CRUZ, R. (2009): "Capítulo II. Competencias (I)”, en TEROL BECERRA, M. J. (dir.): Comentarios al Estatuto de Autonomía para Andalucía, págs. 181-208. Valencia: Tirant lo Blanch.

NúÑEZ LOZANO, M. C. (2001): "Las consultas populares locales”, en Revista Andaluza de Administración Pública, núm. 42, págs. 427-439. 
REALA. Nueva Época - N.o 13, abril-septiembre 2020 - ISSN: 1989-8975 - DOI: 10.24965/reala.i13.10741 - [Págs. 47-74]

Consultas populares y entidades locales: a propósito de la Ley 7/2017, de 27 de diciembre, de Participación Ciudadana de Andalucía Inmaculada Ruiz Magaña

ORDUÑA PRADA, E. (2017): “Democracia local y participación ciudadana: nuevas perspectivas sobre consultas populares municipales", en Anuario del Gobierno Local, núm. 1, págs. 47-92.

PÉREZ ALBERDI, M. R. (2008): "Los derechos de participación en los Estatutos de Autonomía reformados recientemente: especial consideración al Estatuto de Autonomía para Andalucía”, en Revista de Derecho Político, núm. 73, págs. 181-205. DOI: https://doi.org/10.5944/rdp.73.2008.9262.

PÉREZ ALBERDI, M. R. (2014): "Democracia participativa en Andalucía. A propósito del Anteproyecto de Ley de participación ciudadana", en Cuadernos Manuel Giménez Abad, núm. 8, págs. 167-176.

PÉREZ ALBERDI, M. R. (2018): "Referéndum y consultas populares", en TUDELA, J., CASTELLÁ, J. M.,EXPÓSITO, E. y KÖLLING, M. (eds.): Libro Blanco sobre la calidad democrática en España, págs. 221232. Madrid: Marcial Pons.

PÉREZ LÓPEZ, E. (2018): "La participación pública en el ejercicio de la potestad reglamentaria municipal”, en LORA TAMAYO-VALLVÉ, M. (coord.): Retos y nuevas perspectivas de la participación pública, págs. 243-293. Valencia: Tirant lo Blanch.

PÉREZ SOLA, N. (1994): La regulación constitucional del Referéndum. Marmolejo (Jaén): Universidad de Jaén.

PÉREZ SOLA, N. (2009): "La competencia exclusiva de las Comunidades Autónomas en materia de consultas populares”, en Teoría y Realidad Constitucional, núm. 24, págs. 433-454. DOI: https://doi.org/10.5944/ trc.24.2009.6875.

PIZARRO NEVADO, R. (2007): “Artículo 29”, en REBOLLO PUIG, M. (dir.): Comentarios a la Ley Reguladora de las Bases del Régimen Local, págs. 755-771. Valencia: Tirant lo Blanch (Tomo I).

PIZARRO NEVADO, R. (2017): "Entidades y «entes» de ámbito territorial inferior al municipio tras la reforma local de 2013", en Revista de Estudios de la Administración Local y Autonómica, núm. 8, págs. 47-73. DOI: http://dx.doi. org/10.24965/reala.v0i8.10437.

REBOLLO PUIG, M. (1988): "La participación de las entidades representativas de intereses en el procedimiento de elaboración de disposiciones administrativas generales”, en Revista de Administración Pública, núm. 125, págs. 99-166.

REBOLLO PUIG, M. (2007): "Prólogo", en REBOLLO PUIG, M. (dir.), Comentarios a la Ley Reguladora de las Bases del Régimen Local, págs. 7-15. Valencia: Tirant lo Blanch (Tomo I).

REBOLLO PUIG, M. (2017a): "Relaciones entre el ordenamiento estatal y los autonómicos", en REBOLLO PUIG, M. y VERA JURADO, D. (dirs.): Derecho Administrativo, págs. 111-130. Madrid: Tecnos (Tomo I).

REBOLLO PUIG, M. (2017b): "Derecho Administrativo y Administración Pública", en REBOLLO PUIG, M. y VERA JURADO, D. (dirs.): Derecho Administrativo, págs. 27-56. Madrid: Tecnos (Tomo I).

REBOLLO PUIG, M. (2017c): "La potestad reglamentaria”, en REBOLLO PUIG, M. y VERA JURADO, D. (dirs.): Derecho Administrativo, págs. 223-266. Madrid: Tecnos (Tomo I).

RIVERO YSERN, J. L. (2014): Manual de Derecho Local. Huarte: Civitas.

ROBLES MIGUEL, C. (2014): "Disposición adicional”, en DELGADO-IRIBARREN GARCÍA-CAMPERO, M. (coord.): Comentarios a la Ley Orgánica del Régimen Electoral General y a la Ley Orgánica de Referéndum, págs. 1.8961.905. Madrid: La Ley.

RODRÍGUEZ RODRÍGUEZ, J. L. (2001): “Una primera aproximación a la ley de regulación de las consultas populares locales en Andalucía 2/2001, de 3 de mayo", en Revista de Estudios de la Administración Local y Autonómica, núm. 286-287, págs. 457-493. DOI: https://doi.org/10.24965/reala.vi286-287.9121.

RUIZ-RICO RUIZ, C. (2017): Reforma de la Administración Local y problemática jurídico-constitucional. Experiencias de innovación democrática. Valencia: Tirant lo Blanch.

RUIZ-RICO RUIZ, C. y CASTEL GAYÁN, S. (2013): "El derecho autonómico de participación ciudadana: un enfoque constitucional y su desarrollo legislativo", en Revista de Estudios Jurídicos, núm. 13, págs. 1-33.

SÁNCHEZ MORÓN, M. (1979): "El principio de participación en la Constitución Española”, en Revista de Administración Pública, núm. 89, págs. 171-206.

SÁNCHEZ MORÓN, M. (1992): "El sistema político local: fórmulas de gobierno y participación de la ciudadanía", en AA.VV.: Informe sobre el Gobierno Local, págs. 291-321. Madrid: Ministerio para las Administraciones Públicas.

VELASCO CABALLERO, F. (2015): “¿Son aún posibles las consultas municipales? (Francisco Velasco)”, en Instituto de Derecho Local de la Universidad Autónoma de Madrid. Fecha de consulta: 21-06-2019. URL: http://www. idluam.org/blog/son-aun-posibles-las-consultas-municipales-francisco-velasco/. 